IFN Working Paper No. 1122, 2016

\title{
The Role of Institutions in the Migration of Corporate Governance Practice into Emerging Economies - The Case of Africa
}

\author{
Bruce Hearn, Lars Oxelheim and Trond Randøy
}


PRACTICE INTO EMERGING ECONOMIES - THE CASE OF AFRICA

\author{
Bruce Hearn* \\ University of Sussex, UK \\ Lars Oxelheim \\ University of Agder, Norway and Research Institute of Industrial Economics (IFN), Sweden \\ Trond Randøy \\ University of Agder, Norway
}

Keywords: Disclosure; CEO Salary, Institutional Theory; Africa; Emerging Economies; IPO JEL: G23; G38; M12; M14; M16

\title{
Acknowledgements
}

We are grateful to Marv Khammash for Arabic translation of three Egyptian prospectuses and to Lilian de Menezes for Portuguese translation of Cape Verde and Mozambican prospectuses. Financial support from the NasdaqOMX Nordic Foundation is gratefully acknowledged.

*Corresponding author: Bruce Hearn. b.a.hearn@sussex.ac.uk, School of Business, Management and Economics, Jubilee Building, University of Sussex, Brighton. UK. BN1 9SL; Lars Oxelheim lars.c.oxelheim@uia.no, School of Business and Law, University of Agder, Kristiansand, Norway and Research Institute of Industrial Economics (IFN), Stockholm, Sweden, lars.oxelheim@ifn.se; Trond Randøy. trond.randoy@uia.no, School of Business and Law, University of Agder, Kristiansand, Norway 


\begin{abstract}
This study examines the role of the institutional environment in influencing the migration of corporate governance best practice into 22 emerging African economies. Using a unique and comprehensive sample hand-collected sample of 202 IPO firms from across the continent, we adopt a novel institutional logics perspective in studying the diffusion of CEO salary disclosure - a central element of corporate transparency. Our findings reveal that the adoption of CEO salary disclosure by firms is more likely in more homogenous informal institutional contexts. Complementarities arising from disclosure originating from an Anglo-American shareholder value governance framework and indigenous formal institutions adhering to English common law infer disclosure is more likely than in contrasting civil code law contexts. Finally, firms with higher proportions of their boards of directors being drawn from indigenous social elites are less likely to disclose CEO salary - where this is reversed in the context of elevated institutional quality. Our findings are important for regulatory authorities, investors and policy makers alike who are involved in institutional improvements in emerging economies.
\end{abstract}




\section{INTRODUCTION}

Prior research into the international diffusion of corporate governance practices has generally followed one of two approaches: one based on a neoclassical rational adaptation emphasizing convergence on "best practice” which is typically Anglo-American shareholder value (e.g. Haxhi and van Ees, 2010; Coffee, 2001), or a second one based on an institutionalist perspective (e.g. North, 1989, 1994 or Aguilera and Jackson, 2003). We contribute to the comparative institutionalist perspective of Aguilera and Jackson (2003, 2010) and Aguilera et al. (2008) by studying the role of formal and informal institutions in the diffusion of voluntary disclosure (Leftwich et al., 1981; Dye, 1990; Raffournier, 1995, 1997; Leuz and Verrecchia, 2000; Verrecchia, 2001; Ball et al., 2003; Eng and Mak, 2003) of CEO salary at firm-level (Rau, 2015). CEO salary disclosure is a central tenet of the Anglo-American shareholder value framework (Fiss and Zajac, 2004) in terms of reducing bonding costs with external stakeholders (Jensen and Meckling, 1976). It is also an important ingredient in the say-on-pay process (Ferri and Maber, 2013) and of the dynamics of CEO compensation benchmarking (Faulkender and Yang, 2013).

We extend the existing use of institutional theory by adopting the novel institutional logics perspective (see Thornton and Ocasio, 2008 for an overview) in studying the diffusion of corporate governance practice. The notion of "logic" is defined in terms of a set of broad, institutionalized and socially constructed cultural beliefs and rules that structure cognition and fundamentally shape decision-making and action in a field (see Thornton, 2002, 2004, for example). The beliefs and rules also embody certain organizational forms that facilitate the sustenance of underlying institutionalized logics - implying an important sociological explanation of organizational structure. The institutional logics theoretical perspective is particularly useful in accommodating the contextual embeddedness of firms and their governance arrangements (Granovetter, 1985) through its view of society as an inter-institutional and multi-level system (Thornton and Ocasio, 2008). Thus, it yields a flexible, dynamic and historically contingent rationalization of societal structure, institutional environment and optimal organizational forms that are aligned with the internally 
consistent nature of prevailing institutional logics. We argue here that the institutional logics perspective provides a flexible theoretical basis to study the dynamics of organizational forms, which are fundamentally important in understanding diffusion of corporate governance practice.

We claim that existing theoretical perspectives applied to corporate governance migration are subject to significant constraints. Neoclassical perspectives such as rational adaptation are deterministic in assuming a singular "best practice” model upon which all other systems converge (see Aguilera and Cuervo-Cazurra, 2009 for a full review of the literature). As with conventional agency theory, this is under-socialized in lacking consideration of the social context within which the firm is embedded (Granovetter, 1985). Furthermore, these perspectives lack in any consideration of historical contingency. But institutionalists’ perspectives address historical contingency issues although they typically adopt over-socialized views - where the emphasis is placed on broad “aggregate” national institutional frameworks and typologies (see North 1989, 1994 and Aoki, 2001). More recently, Scott’s (1995) triad typology of institutional frameworks based on separable regulatory, normative and cognitive institutional “carriers” - has risen to prominence in the literature. ${ }^{1}$ In contrast, the institutional logics perspective ${ }^{2}$ considers institutions to possess three complementary and inseparable dimensions; these being structural, normative and symbolic or cognitive (Thornton and Ocasio, 2008). This perspective is particularly important since it takes into account the hitherto overlooked normative implications of cognitive institutions. This is exemplified by religion - where this also defines the appropriateness of actions as well as lending legitimacy to regulatory structure - as opposed to being purely cognitive in influence.

\footnotetext{
${ }^{1}$ Regulatory pressure accounts for state-level architecture while normative pressure reflects industry-level professional structures. Cognitive pressure is defined in terms of deeper sociologically acceptability from within society - such as cultural, religious and broad societal norms. Regulatory and normative, on the one hand, are closely related to North (1991) and Williamson’s (2002) definition of “formal” institutions while cognitive equates "informal” counterpart. 2 A central tenet of many institutionalist perspectives is that of isomorphism where DiMaggio and Powell (1983) proposed that coercive, normative and mimetic institutional "pressures" eschew conformity in the organizational structure. However, this concept is limited by being deterministic in nature in assuming a pre-determined dominant organizational form - while institutional logics considers organizational fields to be contested terrain between rival orders - each with its own logic and central organizational form. This contestation between rival logics within a given organizational field has been attributed to structural changes in US healthcare (Scott et al., 2000), higher education publishing (Thornton and Ocasio, 1999), equity markets (Zajac and Westphal, 2004), professional accounting firms (Thornton et al., 2005), and banks (Marquis and Lounsbury, 2007).
} 
We contribute to the nascent comparative corporate governance literature of Aguilera and Jackson (2003, 2010) which considers the infusion of institutional perspectives into the focal firm's boundaries by dynamic coalitions of stakeholders ${ }^{3}$ participating in the firm’s organizational structure. This extends Hoskisson et al.'s (2002) notion of institutionalized “conflicting voices” between rival block shareholders influencing executive decision-making and strategy. Aguilera et al. (2008) adopt a system-based approach to study the costs, complementarities and contingencies of organizations interacting with their respective environments. However, all these approaches consider the firm to be based on an essentially Western corporate bureaucratic structure - rather than itself being a function of the organizational forms arising from the underlying interplay between the dominant institutional logics. We extend these ideas by considering the migration of governance practice - or its diffusion - in terms of being contingent on the dominant institutional logics that form the basis of indigenous societal matrices within which transplanted governance practices are absorbed. A critical contingency of this assimilation process is that of compatibility of organizational forms - between those emphasized as elements of governance practice being migrated and those inherent in the indigenous context.

Corporate Africa provides a unique laboratory for an empirical study of the impact of diffusion of corporate governance practice into emerging economies. We argue the adoption of voluntary CEO salary disclosure in this setting to be an excellent instrument to capture such diffusion of corporate governance practices. Nascent African state apparatus is subject to considerable influences - primarily by market-orientated institutional logics at a trans-national level - typically through macroeconomic structural adjustment programs, conditionality of aid receipts and institutionalized macroeconomic arrangements. Thus, a majority of African nations have established stock exchanges or substantially reformed pre-existing markets during the last twenty years. However, this proliferation of market-orientated logic and associated organizational form based on the Western notion of separation of ownership from control through diversification - is at

\footnotetext{
${ }^{3}$ Aguilera and Jackson (2003, 2010) define these as capital, labor and management - each of which is accompanied by its own set of institutionalized beliefs and values that themselves arise from different demographic areas within society.
} 
odds with sub-national logics emphasizing extended organizational forms based on family or clan kinship. This multi-level contestation of rival logics is ubiquitous across emerging economies with Africa exemplifying these dynamic issues. Our focus on firms undertaking initial public offerings (IPOs) facilitates the study of the institutionalized influences on firms rooted in an underlying societal realm when adopting foreign governance practice tenets in the form of voluntary CEO salary disclosure. The IPO event in effect represents a transition from being based in an indigenous institutional context towards the Anglo-American financial markets logic associated with an organized securities market. The IPO prospectus reflects as deep consideration of what to disclose at the time the firm is "marketed" to prospective investors.

Our empirical findings reveal a probability surface with two opposing effects as regards the absorption of migrating corporate governance practice. The first is that in the context of low institutional quality, higher proportions of social elites on boards of directors lead to a lower likelihood of voluntary disclosure of CEO salary. The second is the opposite of the first - namely in high institutional quality contexts, increasing proportions of social elites on boards of directors lead to a higher likelihood of voluntary disclosure of CEO salary. These opposing effects demonstrate the very different role of social elites within indigenous societies between high and low institutional quality contexts.

The rest of the paper is organized as follows. In the next section, we discuss the theory and formulate our hypotheses. Section 3 outlines the African institutional frameworks while Section 4 covers the sample construction, methodology and definitions of all independent variables. Section 5 contains our discussion while we summarize our findings and provide our policy conclusions in Section 6.

\section{THEORY AND HYPOTHESES}

To understand the emergence of different corporate governance practices across countries, we argue for the appropriateness of using Thornton and Ocasio’s (2008) institutional logics meta-theory - an 
overarching theoretical perspective derived from a wide body of literature. ${ }^{4}$ Institutional logics themselves are internally consistent patterns of social behavior and cultural values that engender reproducibility of social actions and attribute meaning and value to their enactment (Friedland and Alford, 1991). Jackall (1988:112) defines such logics as “the complicated, experientially constructed, and thereby contingent set of rules, premiums and sanctions that men and women in particular contexts create and recreate in such a way that their behavior and accompanying perspective are to some extent regularized and predictable. Put succinctly, an institutional logic is the way a particular social world works”. This definition provides a link between individual agency and cognition on the one hand and socially constructed institutionalized practices and rule structures on the other.

Institutionalized logics emanate from distinct orders within a given society - derived from the realms of the capitalist market, the bureaucratic state, families, democracy and religion (Friedland and Alford, 1991). However, the notion that individuals and executives act as institutional “carriers” - rather than mere actors - through their belonging to multiple societal orders underscores the dynamic nature of the logics perspective. In this way, the logics associated with orders are both influenced by and influence other rival logics in a dynamic system of coalitions, complementarities and conflicts between societal realms. Furthermore, the multilevel character of societal matrices implies that the dynamic interaction between rival logics occurs both at transnational as well as sub-national levels - with this giving rise to considerable governance heterogeneity in the form of multiple co-existing governance frameworks within which firms are embedded.

Logics are internally consistent to the societal orders or realms to which they belong. Friedland and Alford (1991) provide five orders. These are just part of a non-exhaustive list that is in constant flux. As new groups of individuals and organizations coalesce - be it within an industry or in performing an activity - new routines, behaviors and symbolism become institutionalized as

\footnotetext{
${ }^{4}$ To our knowledge, the institutional logic perspective has not been applied to cross-country corporate governance, while is has been successfully applied to behavior in equity markets (Zajac and Westphal, 2004).
} 
an internally consistent logic. The new institutional logics emerging this way has a deeper cognitive significance and legitimacy alongside the ability to shape behavior through notions of appropriateness encapsulated in norms and beliefs - a normative component - as well as the ability to formally structure actions - through behavioral rules, routines and organizational forms (Thornton and Ocasio, 2008). Individuals, such as corporate board members, are viewed as institutional carriers rather than merely as innate actors. Their ability to transgress between multiple societal orders - such as family, state and corporate world - underscores their ability to infuse rival logics into other respective orders. The rival logics are achieved through director interlocks as well as indigenous personnel occupying positions in notionally impartial state bureaucracy. In this setting, they may infuse rival indigenous logics into their structure; which itself is a social construct. Thus, family logics can infuse into and influence those of the state - for example. Society can thus be viewed as a dynamic interactive "soup" of inter-permeable ever changing institutional frameworks.

Western governance practices are institutionally specific in terms of their evolution and are historically contingent on context. Concepts such as the bureaucratic state evolved in early Western European institutional contexts owing to the interplay between merchants, political rulers and the Catholic Church (see North and Thomas, 1970; North, 1993; Milgrom et al., 1990). A combination of the reintroduction of ancient Roman civil code law by the Catholic Church during the medieval period together with the Church's ultimate concession of influence to the newly formed state apparatus across Europe (Kuran, 2005) facilitated the evolution of early organizational structures based on the separation of ownership from control. A similar interplay between state, church and family logics occurred in England - resulted in English common law and the notion of secular political democracy (North and Thomas, 1970; Milgrom et al., 1990). Organizational forms based on diversified ownership necessitated the need for hierarchical control which led to the evolution of rudimentary corporate bureaucracies (Weber, 1978). These bureaucracies were themselves the result of a number of institutional innovations including double-entry book-keeping and limited 
liability contracts (Kuran, 2009). This development then formed the basis for the dominant institutional logics at an international level during the European colonial era - where controlling influence was sought over distant colonies - leading to the transplantation of these bureaucracies into indigenous contexts.

Feudalism is a distinctive characteristic feature across many emerging economies, particularly those of Africa. Bhappu (2000) argues that "feudalism in Europe was based on the rights and duties defined by the relations of the lord and vassal" - where this ultimately led to greater individualism and a more "nuclear" definition of familial structures based on immediate family ties. However, this form of feudalism is very different from the dominance-submission relations between both Arab and African patriarchs and their family members (Sidani and Thornberry, 2013). These relations center on a more "vertically" orientated subordinate duty to parents alongside more "horizontally” defined extended reciprocity obligations between family members (Sidani and Thornberry, 2013; Bhappu, 2000). Additional complexity in extended families arises from polygamous practices - where this results in elaborate social systems underscoring any given family member's property rights and capital. ${ }^{5}$ This has led to the description of African society as “... a system of mutually benefiting reciprocities” through which exchange within extended families takes place (Otite, 1978: 10 quoted in Darley and Blankson, 2008: 377). This extended structure - complete with subordination and mutual extended coownership - is embodied in the communitarian communalistic philosophy of Ubuntu (West, 2014) that underscores traditional Sub-Saharan African societies.

Similar extended patrimonial familial and tribal structures exist across Arab and Arabinfluenced societies, such as those across North and Eastern Africa. These structures are typically centered on male family members and - while being patrimonial in nature - represent extended social networks. The process is captured in the concept of Wasta, ${ }^{6}$ which like Ubuntu, has been

\footnotetext{
${ }^{5}$ Polygamy is at odds with European notions of monogamy which forms the basis of nuclear definitions of family.

${ }^{6}$ Berger et al. (2015) define Wasta in terms of three relational constructs. Firstly, Mojamala represents socio-emotional feelings of participants in a transactional relationship, corresponding to stimulating feelings of well-being and enduring friendship. Secondly, Hamola corresponds to human empathy, benevolence and favoritism, which, in a tribal, clan or
} 
likened to Asian Confucianism and Guan’ xi (Berger et al., 2015; Sidani and Thornberry, 2013).

Notable social features of both Wasta philosophy as well as traditional Sub Saharan African extended clans are that of extended benevolence towards wider kin - which has been likened to notions of nepotism (Sidani and Thornberry, 2013) - and the loss of “face” or reputation (Barakat, 1993). This notion of loss of face is an example of the powerful normative component of familial logics. The logics have been attributed to significant conservatism or inbuilt resistance with regard to transparency ${ }^{7}$ and external informational revelation within family governance systems (Barakat, 1993; Sidani and Thornberry, 2013).

Religion is an equally powerful logic within societies - where this is both in conflict with and in support of familial logics. Its ethical prescriptions are supportive of family and clan notions of morality. However, religion is also conflictual with family logics - where it seeks to regulate potential social flaws and disparities such as those arising from polygamy and inheritance rights. This regulatory role is typified by Islamic shari’ya’s prescriptions regarding marriage and formal codification of inheritance rights (Kuran, 2004). However, Islamic shari’ya as well as the traditional African religion’s (embodied in Ubuntu philosophy - see West, 2014) egalitarian, unifying nature is also evident in its acting as a governance structure across social, political and economic realms. This much more all-encompassing governance role is very different from the secularity of its Christian counterpart that was so central in the evolution of European institutions prior to their transplantation worldwide.

The institutional logics perspective views society as an inherently dynamic multi-level interinstitutional system (Thornton and Ocasio, 2008). While the colonial era transplanted singularly dominant European-origin state and legal frameworks into nascent African nations at a transnational level, these had to contend with equally dominant rival indigenous familial and religious

\footnotetext{
familial context, is often confused with the Western concept of nepotism. Thirdly, Somah is the cognitive component of Wasta, centered on the mutual credence of a relationship. This is based on mutual past history, a tribe's reputation and an individual's personal reputation and past actions.

${ }^{7}$ Transparency is a multifaceted concept with a least common denominator in terms of a lack of information asymmetry between a sender and a receiver of information (Forssbaeck and Oxelheim, 2015). Different levels of transparency reflect the gravity of the existence of such an information asymmetry.
} 
orders at a national and sub-national level. Thus, many emerging economies, and particularly those of African nations, contend with built-in incongruities between societal orders or realms of European origin - such as state and legal architecture - and indigenous familial and religious orders. As a basis for our analysis, we argue that the receptivity of African societies to the diffusion of foreign institutional elements is governed by the relative dominance of indigenous familial and religious logics within the indigenous societal matrix.

In contexts where extended familial and religious logics dominate, there is likely to be a greater subversion of state bureaucracy associated with essentially impartial European transplanted orders - such as state and legal systems. The degree of capture also impacts the degree of assimilation of foreign governance elements and their successful institutionalization within indigenous frameworks. This process is then reliant on complementarities where complementarities refer to situations where the viability - efficacy or efficiency - of an individual institutional element increases in the presence of another institutional element or elements (Aguilera and Jackson, 2003). Such a situation will be particularly true when institutional elements endogenously develop in one domain and are then selectively transplanted into another alien domain or societal matrix (Aoki, 2001).

Typically, the transplanted institutional elements have an enhanced viability in the presence of other elements drawn from the same original domain (Aguilera and Jackson, 2003). Thus, stability and efficiency of institutional elements are enhanced through complementarities generated by their mutual interdependence. In this way, the prevailing “market-orientated” logic that dominates the Anglo-American shareholder value governance framework (Westphal and Zajac, 1994; Fiss and Zajac, 2004) has at its core an organizational form based on separation of ownership from control by ownership diversification (c.f. Berle and Means, 1932). Institutional elements such as voluntary disclosure of CEO salary are deemed to enhance external shareholder liquidity through decreasing their bonding costs (Jensen and Meckling, 1976). Furthermore, the market logic itself is shaped through the interaction of prevailing logics and their respective societal orders within the 
US/UK social context. Thus, both institutionalized logics and their representative organizational form - based on ownership diversification - are at odds with rival indigenous familial and religious logics. Consequently, the assimilation of foreign governance institutions based on a Western markets-orientated logic will be contested by rival indigenous logics.

Based on the institutional logic perspective, we argue that the extensive mutual support between indigenous familial and religious logics underscores a propensity across society for the assimilation of only those foreign elements that are supportive of the underlying sociological structures within society. Hence, while the Western organizational form - complete with accompanying corporate bureaucracy - is adopted, its boundaries are transcended by extended familial structures (Khanna and Palepu, 2001). These structures form the basis for the proliferation of business groups - of nominally legally independent firms that coalesce together under joint strategic leadership by a common entity - typically a family (see Khanna and Yafeh, 2007). Khanna and Yafeh (2007) and Khanna and Rivkin (2001) refer to these as "hybrid” organizational forms. The distinctive "hybrid” governance form attains moral legitimacy (see Suchman, 1995) from the underlying familial and religious logics in terms of its compliance with powerful normative notions of appropriateness (Thornton and Ocasio, 2008). However, it also attains pragmatic legitimacy from its structural conformity with the underlying extended familial networks of social relations - thus, it complies with societal expectations over appropriateness of structure and functioning - where this is centered on familial social dynamics (Suchman, 1995).

\section{The impact of political economy and board-constituent social elites on disclosure}

The colonial era across Africa was marked by the creation of administrative boundaries that delineated the extent of European colonial ambition - where these routinely subverted and dissected underlying indigenous African and Arab clan and ethnic lineage groups (Nunn, 2007, 2008). These groups were often established indigenous states in their own right. Thus, independence marked the formation of new nation states with boundaries from the colonial era (Nunn, 2007, 2008). 
Artificially created feudal systems were, in fact, created on the often fragmented ethnic lineage groups, clans and tribes within their borders. The often narrow control-orientated state apparatus initially transplanted from former European colonial metropoles became absorbed into the underlying feudal system (Joireman, 2001). Social elites empowered at independence acquired control over demographically narrow polities and equally narrow formal state and legal architecture inherited from the colonial era. However, while North $(1989,1994)$ characterizes these elites as being dis-incentivized to initiate institutional reforms that would reduce their private benefits of control, Granovetter (1985) emphasizes the contextual embeddedness of social and economic activity. Thus, elites acquire social status and consequential private benefits associated with this status - but are at same time embedded within underlying feudal systems which is largely a reflection of indigenous familial and religious logics.

The institutional logics perspective views the inherited frameworks, including corporate governance practices, from the former colonial era to form nascent institutional orders in the indigenous nation states. These orders are largely incongruous to their rival indigenous African familial and religious counterparts. The incongruity and the resulting conflict between rival logics extend to a boundary condition in the organizational field - between organizational forms associated with European transplanted logics and those associated with their indigenous counterparts. In the latter case, there is a greater emphasis on extended relationships permeating the firm’s organizational structure with firm boundaries being more "diffuse” in nature, given the greater interaction between nominally independent firms. However, for organizational forms based on indigenous logics to acquire stability and legitimacy, it is necessary for them to adopt a boundary-spanning form that transcends the incongruous logics between state and indigenous logics. Thus, the firm's co-optation of empowered social elites as drawn from the state realm enables the firm to achieve stability in its organizational form as well as legitimacy. Such legitimacy facilitates the firm's access to resources (Pfeffer and Salancik, 1978). 
A corollary to the above arguments is that in the context of dominant familial and religious logics and their consequential influence on organizational forms (based on extended relationships such as business groups) is that these organizational forms are largely incompatible with institutional elements drawn from rival organizational forms centered on ownership diversification. One implication of this is the concept of "face" in family where fears over transparency are representative of a loss of this (Barakat, 1993; Sidani and Thornberry, 2013) leading to deep-rooted inhibitions regarding voluntary disclosure of CEO salary (Verracchi, 2001). A second implication arises from demographically narrower polities being controlled by social elites. Following Granovetter (1985), these, as with all economic and social activity, are contextually embedded. Thus, they are also associated with underlying feudal economies based on rival clans, ethnic lineages or extended clans and families. These economies are dominated by indigenous familial and religious logics with their representative organizational forms being based on internal relational governance as opposed to external third party contracting with investors and stakeholders.

Organizational forms of this kind are incongruous to institutional elements arising from shareholder value organizational forms such as voluntary CEO salary disclosure. Thus, we argue there is a wholesale lack of receptivity within organizations which have co-opted higher proportions of social elites to their boards of directors and voluntary disclosure of CEO salary. As such, we propose the following hypothesis to be tested:

Hypothesis 1. The proportion of social elites serving on the board is inversely associated with disclosure of CEO salary

Furthermore, we argue that the aggregate institutional quality of a country moderates the association in Hypothesis 1. Specifically, we argue that corporate disclosure will vary across countries with different levels of institutional quality. Lower institutional quality is a reflection of an underlying society that is more feudal in nature - with a consequentially demographically narrow polity 
dominated by social elites (see North, 1989, 1994). Indigenous extended familial and religious logics prevail while there is an accentuated incongruity with transplanted European-origin frameworks. In this case, organizational forms based on indigenous logics accommodate those incongruities through hiring social elites who themselves are embedded within a feudal system. These organizational forms are incompatible with institutional elements shaped on foreign organizational structures - such as those based on ownership diversification - and, as such, are not receptive to voluntary CEO salary disclosure. Equally, the prevalence of indigenous familial logics in low institutional quality settings is associated with a powerful normative basis reflected through a fear of loss of face that inhibits transparency and disclosure of salary. As institutional quality improves, so does the social inclusivity of the polity - with European transplanted institutional realms and their associated logics gaining a greater influence in society vis-a-vis their indigenous extended familial and religious counterparts. Higher institutional quality implies a greater emphasis on competitive efficiency for firms to secure resources and less need for legitimacy through selective recruitment of social elites. There is a greater congruity between organizational forms based on prevailing indigenous logics and their foreign counterparts, where these are both centered on ownership diversification. The congruity facilitates the adoption of voluntary CEO salary disclosure as a means to reduce informational asymmetries with external investors.

These arguments lead us to propose a positive moderating role for institutional quality in the negative association between the proportion of social elites on firms' boards and the likelihood of voluntary disclosure of CEO salary. As such, we propose the following hypothesis to be tested:

Hypothesis 2. The inverse negative association between the proportion of social elites on a corporate board and the disclosure of CEO salary is positively moderated by institutional quality.

\section{The association of formal institutional environment with disclosure}


Based on traditional institutional theory arguments, one can posit that the diffusion of governance practices will be based on the degree of institutional complementarities between foreign societal frameworks (from which an institutional element such as CEO salary disclosure is drawn) and the indigenous matrix into which it is transplanted (Jaggi and Low, 2000; Hope, 2003). In contrast, logics theory adopts a more contextually embedded view of this assimilation process based on historical contingency. While the social context of the foreign institutional element is taken into account, the focus is on the indigenous framework.

Assuming that the initial transplantation of European-origin institutional orders took place during the colonial era - notwithstanding subsequent reforms - then African societies are characterized by being either a civil code law or a common law system (Hearn et al., 2016). The former is characterized as being centered on a stakeholder oriented logic. Here, dense inter-firm networks together with weaker protections afforded to minority investor property rights underscore the centrality of block-shareholders as opposed to minority outsiders. Consequently, there is little support for external third party contracting in such systems - where property rights emphasize commitment of capital as opposed to liquidity (Aguilera and Jackson, 2003).

However, the initial colonial-era transplantation was subject to subsequent assimilation and institutionalization within an indigenous societal matrix - giving rise to indigenous societal orders or realms. The orders, in turn, were largely subsumed and incorporated by prevailing dominant logics - these being extended familial and their mutually supporting religious logics. As such, civil code law stakeholder forms of governance were, in effect, subsumed and incorporated into indigenous societal frameworks that also emphasized relational forms of governance - but with these exercised through extended family and clan affiliations. Thus, the diffusion of governance practices based on Anglo-American shareholder value tenets has to contend with incongruities arising from both civil code law stakeholder logics and powerful underlying indigenous familial and religious logics. Accordingly, logics theory predicts there to be little affinity for voluntary CEO salary disclosure in civil code law systems. 
Similarly, in the case of African societies adhering to English common law formal frameworks, the European-originated institutions were assimilated within an indigenous societal framework - dominated by extended familial and religious logics. The historical contingency perspective also views these to be subsumed and incorporated into underlying essentially feudal political economies. However, once these have been transplanted, they retain sufficient original character in order to be receptive to further diffusions of Anglo-American governance practices through their complementarities. Thus, logics theory predicts common law systems to be more receptive towards adopting voluntary CEO salary disclosure. Given these theoretical predictions regarding the differences between common law and civil code law systems, we test the following hypothesis:

Hypothesis 3. Disclosure of CEO salary is more likely in common law jurisdictions than in their civil code law counterparts

\section{The association of the informal institutional environment with disclosure}

A central feature of the successful assimilation of foreign corporate governance elements - such as voluntary CEO salary disclosure - is the compatibility of such elements and the underlying structure of the indigenous political economy. Polities that are ethnically fragmented are more feudal in nature, with this being reflected in the dominance of indigenous familial or clan and religious logics over the relatively impartial European transplanted counterparts. These, in turn, support compatible organizational forms that are based on deeper sociological structures within the fabric of the societal matrix - namely relational forms of governance that are typically in the form of family-centered business groups. These are largely incongruous to comparable organizational forms based on ownership diversification that also form the basis for voluntary CEO salary disclosure. Furthermore, familial or clan logics are resistant towards transparency due to potential loss-of-face concerns (Barakat, 1993; Sidani and Thornberry, 2013). Taken together, institutional 
logics theory suggests there to be little receptivity in indigenous society for the adoption of otherwise incongruous foreign governance elements based on shareholder value governance.

A second feature of feudal systems in ethnically fractionalized societies is one of trust.

Nunn and Wantchekon (2011) find evidence that such fractionalized societies are characterized by a lack of trust in the external governance apparatus as well as towards other clan and ethnic groups. Given the domination of familial and supportive religious logics in such systems, fears about loss of face (Barakat, 1993; Sidani and Thornberry, 2013) with respect to transparency to external entities are accentuated. The fear increases the resistance towards the assimilation of foreign corporate governance elements based on external third party contracting such as voluntary CEO salary disclosure. Thus, we test the following hypothesis:

Hypothesis 4. Disclosure of CEO salary is more likely in environments characterized by a lower fractionalization of informal institutions - such as ethnic diversity

\section{AFRICAN INSTITUTIONAL FRAMEWORKS}

\section{Formal institutions}

The African institutional environment provides a unique context within which to study the diffusion of corporate disclosure. There is a notably sharp divide between civil code law and common law legal systems across the continent (see La Porta et al., 1997, 1998), while it has some of the highest variation in national institutional quality worldwide (Transparency International, 2014). The variation is evident across our sample as detailed in Table 1. Formal political, governmental and legal systems are either overwhelmingly French or Portuguese civil code law on the one hand and English common law on other (Hearn, 2014). This picture underscores the uniqueness and relevance of Africa when studying corporate governance in emerging economies and the developing world as a whole. 
There is a considerable variation within the generic classifications of civil code and common law jurisdictions. But in summary - the legal frameworks across Africa are sharply divided between civil code and common law while there is some variation in the quality of institutions within each category at an individual national level. ${ }^{8}$

\section{Informal institutions}

The African informal institutional context is characterized by religious affiliations - where these are overwhelmingly dominated by Islam - across much of Northern and Eastern Africa, while a variety of traditional beliefs rooted on Ubuntu philosophy (West, 2014) are ubiquitous to Sub Saharan Africa. African indigenous familial frameworks are typically centered on clan-based feudal political economies - where these are often based on ethnicity, reflecting that the continent has the highest ethnic fractionalization worldwide (Collier and Gunning, 1999).

\section{African corporate governance frameworks}

The overwhelming majority of African countries that have established national stock markets have also created a body of national laws with the intention of establishing both an orderly capital market and initiating a corporate governance framework. This pattern is evident from Table 1 where legal statutes generally fall into categories of securities market law, company acts, and regulatory acts. These are often augmented by additional corporate governance codes encapsulating international "best practice" - where these have almost invariably been adopted on an advisory, or informal, basis with only occasional formal legal ratification. Almost all emerging African economies with stock markets also have professional director associations, often formed based on the UK's Institute

\footnotetext{
${ }^{8}$ This is exemplified on the one hand by Algeria and three cantonments (provinces) of Sénégal that were administered as an integral part of metropolitan France while, on the other hand, national frameworks such as that of Egypt were established through Napoleonic conquest but then subject to substantive reform by English common law through incorporation into the British empire. South Africa and, by virtue of colonization, its neighbor Namibia both adhere to Roman-Dutch civil code law - transplanted to Southern Africa prior to the Napoleonic conquest of the Netherlands. However these frameworks have themselves been subject to substantial influence by English common law (Hearn and Piesse, 2014). South Africa and Namibia are examples of Easterly and Levine’s (1997) “settler based systems”, where in these cases, following the initial transplantation of Roman-Dutch civil code institutional frameworks, these subsequently evolved indigenously through an active Afrikaans (an ancient form of Dutch language) speaking judiciary and population.
} 
of Directors model, where these are intended to facilitate the establishment and sustainability of indigenous normative institutions based on a Western-orientated "markets logic".

Finally, emerging economies across the continent are subject to market logics at a transnational level, where these are coercively applied by international financial institutions (such as IMF and the World Bank), state development agencies and former foreign colonial metropolises. These transnational forces influence nascent African economies to adopt one of two corporate governance regimes; the stakeholder-orientated OECD framework or the shareholder valueorientated US/UK Anglo-Saxon model. ${ }^{9}$

\section{Insert Tables 1 and 2}

\section{METHODOLOGY}

\section{Sample construction}

The dataset was constructed in two stages. First, a list of Initial Public Offerings (IPOs) on African markets between January 2000 and January 2014 was identified. In North Africa, these include Algeria, Egypt, Morocco and Tunisia, and in SSA Cape Verde Islands (Bolsa de Valores de Cabo Verde), Cameroon (Bourse de Douala), BRVM (Cote d'Ivoire), Sierra Leone, Malawi, Kenya, Uganda, Rwanda, Tanzania, Seychelles, Zambia, Namibia, Botswana, Mozambique, Mauritius and Ghana. Nigeria was also included but only data between January 2002 and January 2014 was available. Our primary source here was the national stock exchanges and their associated websites and these were cross-checked with lists sourced from major brokerage houses to ensure accuracy in the case of Nigeria and Zambia. This resulted in an "estimated” population of 280 stock listings.

In order to ensure that our population actually covered IPOs and not private placements, the IPO prospectuses were obtained. IPOs included are offerings that produce a genuine diversification

\footnotetext{
${ }^{9}$ The shareholder value-orientated US/UK Anglo-Saxon model is often shaped on the UK model or adopted "second hand" from other English common law countries, such as Botswana's adoption of Sri Lanka's governance code and Malawi's adoption of Kenya's code. South Africa's King governance codes are similar in their emphasis on disclosure to the shareholder value system.
} 
of ownership amongst a base of minority shareholders (as opposed to private placements involving the preferential allocation of stock with institutional or corporate block holders in pre-arranged quantities and prices). Equally, care was taken to avoid misclassifications with registrations, introductions and seasoned (secondary) offerings as these are often also officially referred to as IPOs. Furthermore, IPOs are defined as offerings of ordinary shares with single class voting rights, that is, excluding preferred stock, convertibles, unit and investment trusts as well as readmissions, reorganizations and demergers and transfers of shares between main and development boards. In lieu of these efforts to solely focus on IPOs, our final population is reduced to 202 genuine IPO firms.

Data on IPOs was collected from the financial market regulator websites for Algeria and Morocco while a combination of Thomson Corporation Perfect Information and Al Zawya databases was used for Egyptian prospectuses. The Al Zawya database, the national stock exchange and direct contact with individual firms were used to source prospectuses for Tunisia. Similarly in SSA, the prospectuses were from the Ghanaian, Tanzanian, Cape Verdean, and Sierra Leone national stock exchanges and the exchange websites in the case of the Seychelles and Cameroon. The Thomson Corporation Perfect Information database was used in the first instance to source prospectuses from Nigeria, Malawi and Kenya. Pangea Stockbrokers (Zambia) as well as individual floated firms provided prospectuses for the Zambian stock market. Finally, in SSA, the African Financials website (2014) provided information relevant to listing from annual reports.

Considerable care was taken in the interpretation of information from IPO listings prospectuses, given the considerable variation in size and quality of these filings across the continent. Examples range from inaccuracies in values and units of measurement in Egypt (such as units stipulated in prospectuses as billions where additional verification confirmed value denominated in millions) to omissions and inaccuracies in the balance sheets in the prospectuses of many smaller Nigerian firms. Attempts to verify data from prospectuses with additional sources 
such as firm websites, annual reports and mandatory filings of annual accounts were made wherever possible.

Finally, it is notable that of our population of 202 genuine IPOs, 18 had missing values in terms of published age - or year of IPO firm establishment in prospectuses - resulting in the final sample of 184 IPOs. The 18 missing observations are evenly distributed throughout the sample.

\section{Dependent variables}

Our dependent variable is a binary value of 1 if the IPO firm discloses an annual fixed base cash salary of CEO in listing prospectus and 0 otherwise. A number of well recognized studies do previously have such a binary dependent variable in addressing firm's voluntary adoption of aspects of corporate governance legislation or best practice such as Allcock and Filatotchev (2010) focussing on variable performance-contingent pay in UK IPO firms, Chizema (2008) focussing on CEO salary disclosure in Germany, a number of other similar studies focussing on Germany (e.g. Fiss and Zajac, 2004), and Haxhi and van Ees (2010) in a study of worldwide diffusion of corporate governance codes.

The use of a binary (1/0) dependent variable in relation to one specific element of corporate governance is simple as well as intuitive, given the complexity of a multi-country dataset which focuses on emerging economies. These are notably characterized both by significant differences in their institutional framework and by levels of disclosure on a broader basis. Despite these obvious differences in the two principal formal corporate governance regimes that have taken hold across the African continent, a common theme is optimal disclosure to external stakeholders including shareholders. This underscores our focus on the centrality of voluntary disclosure of CEO salary.

\section{Explanatory variables}

Our first explanatory variable is the proportion of all board members that belong to the social elites. This variable is relevant to Hypotheses 1 and 2. Following the reporting requirements used in the 
African IPO prospectuses, we are able to identify four different categories of social elites: senior military; government; commercial; and academic. ${ }^{10}$ We adopt a singular-dimensioned definition whereby an individual director is defined in terms of the social elite status or background as described in the director profiles part of the IPO listings prospectus. We further verify this information from additional sources - as reported in Appendix Table 1. The adoption of a singulardimensioned social elite defined by the four categories but not several of these backgrounds together is analytically tractable and is in line with the director profile descriptions- where a singular-definition is routinely applied. However, we concede that it is quite possible for a director to emanate from a number of categories of elite - such as directors with a former military background also having served in government and commercial roles. Our definition is drawn from the reporting prevalent in African IPO prospectuses. Furthermore, the list of four identifiable elites may not be exhaustive but it is once more based on those reported formally in the listings prospectuses and adheres to national regulatory requirements.

Our second explanatory variable is a binary legal origin dummy variable adopting the value of 1 if the jurisdiction is civil code law and 0 for the alternative common law. This variable refers to Hypothesis 3.

Finally, our third explanatory variable refers to ethnic fractionalization - the focus of Hypothesis 4 - with this sourced from the NSD Macro data website (see Appendix Table 2). This metric corresponds to a bespoke index capturing ethnic diversity.

\section{Moderation variables}

We use our institutional quality metric to moderate the association between the proportion of social elites on the board of directors and the likelihood of disclosure of CEO salary. This is an aggregate variable and it is constructed from an equally weighted average of six World Bank governance

\footnotetext{
${ }^{10}$ The four elites are defined as: government elites drawn from senior civil service appointments, roles of former president, prime minister, diplomatic and ambassadorial roles. Commercial elites being drawn from prestigious bluechip directorships, commercial attaché roles and board level roles in national chambers of commerce. Military elites are drawn from ranks of Air Force - Group Captain and above, Navy - Captain and above, and Army - Brigadier and above. Academic elites are drawn from professorial appointments and above.
} 
metrics (Kaufman et al., 2009). Detailed definitions of the six metrics are provided in Appendix Table 2. These six have been rebased to a $0-10$ scale prior to aggregation. ${ }^{11}$ We follow Liu et al. (2014) in moderating with an index. This corresponds to Hypothesis 2.

\section{Control variables}

We use a number of distinct sets of control variables. The first set is institutional control where the only variable is defined above.

Our second set of control variables refers to four board control variables. The first two of these variables are natural logarithm of board size, defined as total number of executive and nonexecutive directors and the ratio outside nonexecutives defined as the proportion of independent outsider nonexecutives to board size. The former accounts for enhanced access to resources through the director's personal networks in the form of human and social capital (Boyd, 1994; Pfeffer and Salancik, 1978) as well as the managerial and coordination capability of the board in terms of communication and free-riding (Boyd, 1994). The latter accounts for the quality of monitoring, where independent nonexecutives are unaffiliated with insider networks and influence from controlling groups or CEO (Fama and Jensen, 1983). Our third board control variable is that of the ratio of business group affiliated directors on the board. This variable captures the prevalence of business groups in African economies (Hearn and Piesse, 2013; Hearn, 2014) but also their dominance of economic and social activity. Their presence is representative of social network multiplexity across indigenous societies, which acts to strengthen indigenous informal frameworks. We draw on the additional sources detailed in Appendix 1 to identify business groups and then affiliated directors through director profiles of listings prospectuses. Our fourth board control is the proportion of foreign nonexecutives that are unaffiliated with any multinational enterprise (MNE) or corporate block entity, i.e. that are independently recruited to total board size. This variable

\footnotetext{
${ }^{11}$ We use this variable under the assumption of equi-distance.
} 
controls for an important route of infusion of institutional logics into the focal firm that may enhance the probability of disclosure of CEO salary (Oxelheim and Randøy, 2003).

Our third set of control variables refers to firm-specific control variables and contains four variables. Here, we use the natural logarithm of firms' pre-tax revenues (or sales) as a proxy for size, in line with Sanders and Carpenter (1998) and Finkelstein and Boyd (1998). This is representative of the complexity of a given firm's operations and thus mirrors the complexity of the task environment which, in turn, is reflective of the information processing requirements of the board. We adopt the accounting return on assets (ROA) ${ }^{12}$ as a measure of firm performance in line with Finkelstein and Boyd (1998) and Khanna and Palepu (2000). We also control for firm age where older firms are anticipated to have larger, more complex operations mirroring more complex task environments. This variable also controls for the "liability of newness" and the considerable information asymmetries generated by a lack of operational and performance history (Arthurs et al., 2008). Finally, following Andersen et al. (2003), we introduce a financial leverage or gearing control which is the ratio of debt to equity. ${ }^{13}$ This variable captures the differential use of debt as opposed to equity as a governance mechanism as well as the degree and type of financing corresponding to where the firm is positioned in its lifecycle of development.

As our fourth set of control variables, we use three ownership control variables to account for concentrated holdings of aggregate board, state entities and CEO. These holdings represent the mechanism through which these entities can exert significant coercive institutional pressures into the firm’s organizational structure (DiMaggio and Powell, 1983).

\footnotetext{
12 ROA is conventionally defined as ROA = ((Net Income + Interest*(1 - Tax Rate) $) /$ Total Assets) (see Khanna and Palepu, 2000). However, due to a significant variation in the data arising from varying reporting standards across Africa with the frequent omission of reported interest income and corporate taxation rates from listings prospectuses, we use a modified version of this, namely ROA = (Net Income/ Total Assets). However, while both measures suffer from business cycle effects and are not forward looking, they provide a representative indication of firm performance subject to the data limitations prevalent to emerging economies.

${ }^{13}$ In contrast to Bruton et al. (2010) where the ratio of debt to assets was used, we use the debt-to-equity ratio. Whilst this is vulnerable to variations between the static accounting valuation of equity as opposed to market-valuation and is vulnerable to business cycles, it captures the preferences for the use of debt and, importantly, captures the degree to which debt is used in conjunction with its being a "rules-based" governance instrument limiting managerial discretion and mitigating potential agency conflicts.
} 
Finally, as a fifth set of control variables, we use three IPO specific control variables. The first accounts for the demand for external equity finance in terms of the number of shares issued at IPO to the total shares issued by the firm post-IPO, where these values are sourced from listings prospectuses. Including this variable follows the intuition of Hoskisson et al. (2002) in terms of the introduction of new owners within the firm generating "conflicting voices” in terms of firm strategy and executive decision-making. The conflicting voices arising from owners are also viewed as sources of coercive institutional pressures infusing into the organizational structure. The second and third control variables are related to the lead managers involved in the IPO. The variables are lead manager reputation and a binary dummy accounting for whether the lead manager is foreign (or not). The lead manager reputation is constructed using the new metric introduced by Hearn (2014). This is estimated as the average of two market power measures. The first follows Megginson and Weiss (1991) and is the proportion of funds raised by firms using the lead manager to all funds raised by all firms, while the second is the proportion of IPOs with which the lead manager has been involved to the total IPO population. Both reflect the importance of the lead manager as a potential vehicle for infusing rival institutionalized logics into the firm and thereby influencing the likelihood of voluntary CEO salary disclosure.

\section{Empirical Model}

We use Binomial probit models to test each of the four hypotheses alongside our controls. Four models are tested in total. The first, model 1 , includes the ratio of social elites on boards of directors in accordance with Hypothesis 1 . Model 2 includes the explanatory variable in model 1 as well as the moderation variable - formed from the product of the ratio of social elites on the board and institutional quality in accordance with Hypothesis 2. Model 3 includes all preceding explanatory variables as well as our legal origin variable (civil code law dummy) in accordance with Hypothesis 3. Finally, model 4 includes all preceding explanatory variables plus the ethnic fractionalization variable in accordance with our Hypothesis 4. 
Additional country fixed effects are not used - given that the differences between countries are accounted for by institutional quality or common law legal origin - so as to avoid the dummy variable trap (Wooldridge, 2009). ${ }^{14}$ Industry and time (year) fixed effects are applied across all models. Industry controls capture industry diversification differences - a key feature in emerging economy business groups (Khanna and Palepu, 2000) while year effects relate to the variation in institutional development and improvements in regulations, capital market culture and surveillance environment. The industry definitions vary across each country (see Khanna and Rivkin, 2001 for details of similar issues in a comparable study of 14 emerging economies) leading us to adopt Bloomberg basic industry definitions. ${ }^{15}$ Our probit model is:

$$
\begin{aligned}
& y^{*}=\alpha+\sum \beta X+\varepsilon_{i, t}, \varepsilon_{i, t}=N(0,1) \\
& \beta X=\beta_{1} \text { Explanatory and moderating variables }{ }_{t} \\
& +\beta_{2} \text { Board controls }_{i, t-1} \\
& +\beta_{3} \text { Firm specific controls }{ }_{i, t-1} \\
& +\beta_{4} \text { Ownership controls }_{i, t-1} \\
& +\beta_{5} \text { IPO controls }_{i, t-1} \\
& +\delta_{1} \text { Industry F.E. }+\delta_{2} \text { Time F.E. } \\
& \text { If } y^{*} \geq 0, y=1 \\
& \text { If } y^{*}<0, y=0
\end{aligned}
$$

where $t$ designates time at IPO, $t$ - 1 denotes the year preceding the IPO event and $i$ denotes individual firm-level values. The dependent variable is a binary dummy (1/0) in each case for the likelihood of disclosure of CEO salary. F.E. denotes fixed effects. All other controls are as defined in the preceding section.

\footnotetext{
${ }^{14}$ If dummy variables for all country (and time) categories were included, their sum would equal 1 for all observations, which is identical to and hence perfectly correlated with the vector-of-ones variable whose coefficient is the constant term; if the vector-of-ones variable were also present, this would result in perfect multicollinearity, so that the matrix inversion in the estimation algorithm would be impossible. This is referred to as the dummy variable trap (Wooldridge, 2009)

${ }^{15}$ Industry classifications are: Basic Materials; Consumer Goods Non-Cyclical; Consumer Goods Cyclical; Energy; Financials; Health; Industrials; Technology; Telecommunications; Utilities. The identification of firms according to their industry using broad Bloomberg definitions is in keeping with data limitations across our sample, which is a prevalent characteristic of emerging economies.
} 


\section{EMPIRICAL RESULTS}

\section{Bivariate analysis}

Correlation patterns amongst all our independent variables - as reported in Table 3 - reveal low associations between them all and a general lack of statistical significance. This mitigates concerns over multicollinearity. However, the table also reveals statistical significance at a bivariate level for the association between our dependent and some of our explanatory variables.

\section{Table 3}

\section{Multivariate analysis}

The results from hypothesis testing are reported in Table 4. Here, we find some support for Hypothesis 1 for three models while support for Hypothesis 2 is restricted to model 4. Strong statistical significance is found for Hypothesis 3 and Hypothesis 4.

The associations between the dependent variable and all our controls are generally consistent across models. CEO salary disclosure is negatively associated with the size of boards of directors $(p \leq 0.05)$ and the levels of gearing, i.e. less debt in relation to equity ( $\leq \leq 0.005)$. The disclosure is positively associated with the size of the firm in terms of revenues $(p \leq 0.10)$, performance in terms of ROA $(p \leq 0.05)$ and CEO ownership ( $\leq \leq 0.05)$. Voluntary disclosure of CEO salary is also positively associated with the lead manager being foreign $(p \leq 0.005)$ and negatively associated with the lead manager having a weak reputation - i.e. less involvement in IPO issuances $(p \leq 0.005)$.

We compare models by appraising the three informational-loss criterion metrics - AIC, SBC and HQC - alongside the log-likelihood ratio statistic and the (pseudo) McFaddon R ${ }^{2}$. Model 4 has a combination of the highest (pseudo) McFaddon $\mathrm{R}^{2}$ (35.60\%) and log-likelihood ratio values (90.68) alongside the lowest scores across all three informational-loss criteria (1.348 AIC, 2.082 SBC and 1.646 HQC). Model 4 also provides a parsimonious test of all our hypotheses jointly in a 
multivariate context. This underscores the importance of our unique approach in considering the influence of ethnic fractionalization within societies recipient to the diffusion of governance practice.

\section{Table 4}

Finally, we explore the moderating association between the ratio of social elites on the board and the likelihood of CEO salary disclosure with institutional quality in Figure 1. This graphically depicts a probability surface - based on a cumulative Normal probability distribution. In order to ascertain the range over which to represent the proportion of social elites on the board in its association with the dependent variable of likelihood of CEO salary disclosure, we adopt a minimum of zero and a maximum of the nearest rounded value to the sum of the mean $(0.13)$ plus one standard deviation- ${ }^{16}$ While this upper bound is 0.31 , we round this upwards to 0.35 - equating to $35 \%$ of a given board's nonexecutives comprised of social elites.

The probability surface reveals two opposing effects. The first is that in the context of low institutional quality, higher proportions of social elites on boards of directors lead to a lower likelihood of voluntary disclosure of CEO salary. The second is the opposite of the first - namely in high institutional quality contexts, increasing proportions of social elites on boards of directors lead to a higher likelihood of voluntary disclosure of CEO salary. These opposing effects demonstrate the very different role of social elites within indigenous societies between high and low institutional quality contexts.

In low institutional contexts, elites are associated with a demographically narrow polity which itself is the result of an underlying feudal governance system. Elites have considerable vested private benefits of control associated with their elevated status and their being able to exploit very different notions of property rights. The benefits arise from elites’ participation in European-

\footnotetext{
${ }^{16}$ One standard deviation is equal to $0.18(18 \%)$ - these are not reported, for brevity, but are available from the authors upon request. We follow Chizema et al. (2015) in providing a graphical display of moderating associations and in forming our upper and lower limits.
} 
orientated societal orders - such as state and legal system - on the one hand, while on the other they are inextricably embedded in the underlying feudal system where longevity and commitment are emphasized. Under such circumstances, elites are able to protect their private benefits as well as avoid losing reputational "face" in front of their clan or extended family. In the context that elites are associated with state architecture and formal frameworks that have considerable legitimacy amongst society. This comes with an emphasis on market logics reflected in a greater focus on competitive efficiencies and enhanced transparency, where the technologies for such appropriation are rendered more costly through enhanced institutional quality.

\section{Figure 1}

\section{DISCUSSION AND CONCLUSIONS}

\section{Theoretical implications and contributions}

Our findings provide substantive support for the application of the institutional logics theoretical perspective in the study of the diffusion of firm-level corporate governance "best practices" within the African context. We argue that the same theoretical arguments could also be applied more broadly across emerging economies. We measure the transfer of such corporate governance practice through the diffusion of voluntary disclosure of CEO salary - a central tenet of AngloAmerican shareholder value governance - in the institutionally heterogeneous setting of Africa. More broadly, we also suggest that our findings lend support to the relevance of indigoes structures when assessing corporate governance across emerging economies.

We maintain that the institutional logics perspective helps to rationalize the multi-level inter-institutional structure of emerging economy firms, as it considers heterogeneity both between and within societies. In our study, this is shown by the fact that we observe less corporate disclosure (CEO salary in our case) when there is a strong presence of social elites within corporate boards. Therefore, we argue that this perspective is particularly useful given the incongruities that exist 
across many developing and emerging economies between formal and informal frameworks where the former originates from colonial-era transplantation and the latter is predominantly communitarian. Shortfalls in traditional institutionalist approaches (e.g. North, 1990, 1994 and Aoki, 2001) center on broad aggregate level constructs with the assumptions of institutional uniformity and homogeneity nationally - which have been equated to being “over-socialized” in nature. Conversely, rational adaption theorists (e.g. Coffee, 2001) are inherently "under-socialized" in assuming worldwide diffusion of "best practice" governance codes are the natural outcome of competitive forces in the attraction of foreign investment. These wholly omit any consideration of social structure from consideration.

Our application of the institutional logics approach provides valuable insights into firms' choice of corporate governance practices within emerging and developing nations - where indigenous social elites are routinely recruited to boards of directors in order to co-opt environmental contingencies. Based on institutional logics theory, we propose that a boundaryspanning activity provides stability to organizational forms that are associated with indigenous and mutually supportive religious societal orders that, at same time, need to attain legitimacy from demographically narrow European-originated formal state and legal frameworks. This is particularly true in contexts where nations are essentially governed by feudal systems where there is an inbuilt incongruity between indigenous familial and religious logics on one hand and Europeanoriginated logics transplanted during the colonial era. Thus, the co-optation of social elites diffuses tension associated with this incongruity, enabling the firm to attain legitimacy and consequential access to resources and markets. However, the firm's essential organizational structure is that associated with prevailing familial and religious logics - namely based on extended family or clan affiliations and inherently relational in nature.

Given the internal socialized nature of this - there is little propensity towards adopting corporate governance measures that themselves are based on a very different model of ownership diversification - such as voluntary CEO salary disclosure. Furthermore, deep-seated familial 
concerns over loss of “face” generate inhibitions towards disclosure. In line with Granovetter's (1985) embeddedness thesis - we argue that firms and social elites alike are inextricably embedded within underlying feudal systems. This corroborates our findings of higher proportions of boards of directors drawn from social elites being associated with lower levels of disclosure in CEO salary.

Our findings support the notion of institutional complementarities in African firms' choice of corporate governance practices. We argue that institutional elements of corporate governance that endogenously originate from "common law" settings - such as the US and the UK - attain greater efficiency, efficacy and viability when transplanted into matrices with other elements drawn from the same origins - namely those of "common law". Thus, we observe that a voluntary disclosure of CEO salary is much more likely to be adopted in common law jurisdictions where the mutual independencies of similarly originated institutional elements enhance the viability of such disclosure.

Finally, our last finding reflects the limitations of overarching institutionalist perspectives centering on a singular "national governance system” and the deterministic nature of isomorphism where confluence onto a predetermined organizational form is assumed. The degree of societal fractionalization - be this ethnic, linguistic or religious - is an important indicator of the uniformity and homogeneity of a given society. The logics perspective views elevated fractionalization in terms of being associated with demographically narrower polities serving special interests drawn from what is, in effect, an underlying feudal system. Ethnic fragmentation leads to lower levels of trust across societies as well as between individual ethnicities and the external governance apparatus (Nunn and Wantchekon, 2011).

Furthermore, the feudal nature of ethnically fragmented societies implies that an indigenous society will be dominated by extended familial - in the form of clan or tribal - logics with these often being mutually supported by religious logics. This pattern, in turn, supports internal relational governance forms - loosely based on dominant underlying sociological structures within society namely extended familial or tribal affiliations - with organizational forms reflecting this. Our 
findings support these arguments with strongly significant associations between increasing ethnic fractionalization and reduced voluntary disclosure of CEO salary. This result supports the premise that ethnic fractionalization is paralleled by feudal governance systems leading to a lack of trust and a dominance of logics that are incongruous to the Western market-orientated logics with which disclosure and transparency are associated.

Our public policy recommendation, to international development agencies and national regulatory authorities, is that corporate governance policies should broaden the perspective of the debate when selecting appropriate theoretical perspectives behind corporate governance policy formation.

\section{Limitations and Future Directions}

Our results lead us to question the conventional wisdom of the universality of "corporate governance best practice”, commonly with the concept of corporate governance convergence at its center. The results have implications in terms of the limitations in promoting economic development policy. A considerable part of such policies tends to be shaped on neoclassical and rational adaptation perspectives, the universality of Western style business education and associated global industry norms. In contrast, our findings may indicate for further research an important role for the demographic shape and composition of the indigenous political economy, being itself shaped by existing legal and institutional frameworks and less so by Anglo-American corporate governance "best practice" tenets. One limitation with our study is our focus on the diffusion of a single institutional element, i.e. the voluntary disclosure of CEO salary. While this provides a useful focus - in terms of avoiding potential shortfalls associated with aggregation bias from using a broader dimensioned disclosure index and in terms of the limitations of data availability in an emerging economy sample - it would be preferable to widen the scope of the analysis.

A second limitation relates to the geographic focus of the sample - with this being limited to the African continent. While this is beneficial in terms of the considerable variation in institutional 
quality, demographic structure and composition of polity and societal fractionalization - a useful extension would be to apply our model to a broader worldwide sample in order to ascertain optimal generalizability. This broader application could provide the focus of further research, applying the distinctive actor-centered institution-theoretic model. 


\section{REFERENCES}

African Financials website. (2014). African Financial Statements and Annual Reports. http://www.africanfinancials.com/ Accessed 15 September 2014

Aguilera, R. V. \& Jackson, G. (2003). The cross-national diversity of corporate governance: Dimensions and determinants. Academy of Management Review, 28(3), 447-465

Aguilera, R. V., Filatotchev, I., Gospel, H., \& Jackson, G. (2008). An organizational approach to comparative corporate governance: Costs, contingencies, and complementarities.

Organization Science, 19(3), 475-492

Aguilera, R. V. \& Cuervo-Cazurra, A. (2009). Codes of Good Governance. Corporate Governance: An International Review, 17(3), 376-387

Aguilera R.V. \& Jackson, G. (2010). Comparative and international corporate governance. The Academy of Management Annals 4(1), 485-556

Allcock, D., \& Filatotchev, I. (2010). Executive incentive schemes in Initial Public Offerings: the effects of multiple agency conflicts and corporate governance. Journal of Management, 36(3), 663-686

Anderson, R. C., \& Reeb, D. M. (2003). Founding-Family Ownership and Firm Performance: Evidence from the S\&P 500. Journal of Finance, 58(3), 1301-1328

Aoki M. (2001). Toward a comparative institutional analysis. Cambridge, MA: MIT Press.

Arthurs J., Hoskisson R., Busenitz L., \& Johnson R. (2008). Managerial agents watching other agents: multiple agency conflicts regarding underpricing in IPO firms. Academy of Management Journal 51, 277-294

Barakat, H. (1993). “The Arab family and the challenge of change”, in The Arab World, ed. Haim Barakat, University of California Press

Berger R., Silbiger A., Herstein R., \& Branes B. R. (2015). Analyzing business-to-business relationships in an Arab context. Journal of World Business 50, 454-464 
Berle, A., \& Means, G. (1932). The modern corporation and private property, ed: Adolf A. Berle and Gardinar C. Means, The Macmillan Company, New York

Bhappu, A. D. (2000). The Japanese family: An institutional logic for Japanese corporate networks and Japanese management. The Academy of Management Review, 25(2), 409-415

Boyd, B. K. 1994. Board control and CEO compensation. Strategic Management Journal, 15(5), 335-344

Chizema, A. (2008). Institutions and voluntary compliance: The disclosure of individual executive pay in Germany. Corporate Governance: An International Review, 16(4), 359-374

Coffee, J. C. Jr. (2001). The Rise of Dispersed Ownership: The Roles of Law and the State in the Separation of Ownership and Control. The Yale Law Journal, 111(1), 1-82

Collier, P., \& Gunning J. W. (1999). Why has Africa grown slowly? Journal of Economic Perspectives 13(3), 3-22.

Darley, W. K. \& Blankson, C. (2008). African culture and business markets: Implications for marketing practices. Journal of Business and Industrial Marketing, 23(6), 374-383

DiMaggio, P., \& Powell, W. (1983). The iron cage revisited: institutional isomorphism and collective rationality in organizational fields. American Sociological Review, 48, 147-160

Dye, R. A. (1990). Mandatory versus Voluntary Disclosures: The Cases of Financial and Real Externalities. Accounting Review, 65 (1), 1-24

Easterly, W., \& Levine, R. (1997). Africa's Growth Tragedy: Policies and Ethnic Division. Quarterly Journal of Economics 112, 1203-1250

Eng, L. L. \& Mak, Y. T. (2003). Corporate Governance and Voluntary Disclosure. Journal of Accounting and Public Policy, 22 (4), 325-45

Fama, E. F. (1980). Agency problems and the theory of the firm. Journal of Political Economy 88, 288-306

Fama, E. F., \& Jensen, M. C. (1983). Separation of ownership and control. Journal of Law and Economics, 26(2), 301-325 
Faulkender, M. \& Yang, J (2013). Is disclosure an effective cleansing mechanism? The dynamics of compensation peer benchmarking. Review of Financial Studies, 26, 806-839.

Ferri, F. \& Maber, D. (2013). Say on pay votes and CEO compensation: Evidence from the UK. Review of Finance, 17, 527-563.

Fiss, P. C., \& Zajac, E. J. (2004). The diffusion of ideas over contested terrain: The (non) adoption of a shareholder value orientation among German firms. Administrative Science Quarterly, 49(4), 501-534

Finkelstein, S., \& Boyd, B. K. (1998). How much does the CEO matter? The role of managerial discretion in the setting of CEO compensation. Academy of Management Journal, 41, 179199

Forssbaeck, J. \& Oxelheim, L. (2015). Oxford handbook of economic and institutional transparency. New York: Oxford University Press.

Friedland, R., \& Alford, R. R. (1991). „Bringing society back in: Symbols, practices, and institutional contradictions”, in The New Institutionalism in Organizational Analysis, ed. Walter W. Powell and Paul J. DiMaggio, pp 232-263. Chicago: University of Chicago Press

Granovetter, M. (1985). Economic action and social structure: The problem of embeddedness. American Journal of Sociology, 91(3), 481-510

Haxhi, I. \& van Ees, H. (2010). Explaining diversity in the worldwide diffusion of codes of good governance. Journal of International Business Studies, 41(4), 710-726

Hearn, B. (2014). The political institutional and firm governance determinants of liquidity: Evidence from North Africa and the Arab Spring. Journal of International Financial Markets, Institutions \& Money, 31, 127-158

Hearn, B., \& Piesse, J. (2013). Firm level governance and institutional determinants of liquidity: Evidence from Sub Saharan Africa. International Review of Financial Analysis, 28, 93-111 
Hearn, B., Oxelheim, L., \& Randøy, T. (2016, forthcoming). The institutional determinants of private equity involvement in business groups - The case of Africa. Journal of World Business, forthcoming

Hope, O.-K. (2003). Firm-level disclosures and the relative roles of culture and legal origin. Journal of International Financial Management and Accounting 14, 218-248

Hoskisson, R. E., Hitt, M. A., Johnson, R. A. \& Grossman, W. (2002). Conflicting voices: the effects of institutional ownership heterogeneity and internal governance on corporate innovation strategies. The Academy of Management Journal, 45(4), 697-716

Jackall, R. (1988). Moral mazes: The world of corporate managers. New York: Oxford University Press

Jaggi, B. \& Low, P. Y. (2000). Impact of culture, market force, and legal system on financial disclosure. International Journal of Accounting 35, 495-519.

Joireman S F (2001). Inherited legal systems and effective rule of law: Africa and the colonial legacy. Journal of Modern African Studies, 39(4), 571-596

Kaufman, D., Kraay, A., \& Mastruzzi, M. (2009). Governance Matters VIII: Governance Indicators for 1996-2008. World Bank Policy Research Unit, June 2009

Khanna, T., \& Palepu, K. (2000). Is group affiliation profitable in emerging markets? An analysis of diversified Indian business groups. Journal of Finance, 55(2), 867-891

Khanna, T., \& Rivkin, J. W. (2001). Estimating the performance effects of business groups in emerging markets. Strategic Management Journal, 22, 45-74

Khanna, T., \& Yafeh, Y. (2007). Business Groups in Emerging Markets: Paragons or Parasites? Journal of Economic Literature, 45(2), 331-372

Kuran, T. (2004). Why the Middle East is economically underdeveloped: Historical mechanisms of institutional stagnation. Journal of Economic Perspectives, 18 (3), 71-90

Kuran, T. (2005). The logic of financial westernization in the Middle East. Journal of Economic Behaviour and Organization, 56, 593-615 
Kuran, T. (2009). Explaining the economic trajectories of civilizations: The systemic approach. Journal of Economic Behaviour and Organization, 71, 593-605

La Porta, R., Lopez-de-Silanes, F., Schliefer, A., \& Vishny, R. (1997). Legal Determinants of External Finance. Journal of Finance, 52, 1131-1150

La Porta, R., Lopez-de-Silanes, F., Schliefer, A., \& Vishny, R. (1998). Law and Finance. Journal of Political Economy, 106(6), 1113-1155

Leftwich, R., Watts, R. \& Zimmerman, J. (1981). Voluntary Corporate Disclosure: The Case of Interim Reporting. Journal of Accounting Research, 19 (supplement), 50-77.

Leuz, C. \& Verrecchia, R. E. (2000). The Economic Consequences of Increased Disclosure. Journal of Accounting Research, 38 (supplement), 91-124.

Liu, X., Lu, J., \& Chizema, A. (2014). Top executive compensation, regional institutions and Chinese OFDI. Journal of World Business, 49, 143-155

Marquis, C., \& Lounsbury, M. (2007). Vive La Resistance: Competing logics and the consolidation of the US community banking. Academy of Management Journal, 50(4), 799-820

Megginson, W.L., Weiss, K.A. (1991). Venture capitalist certification in initial public offerings. Journal of Finance 54, 879-903.

Milgrom, P. R., North, D. C., \& Weingast, B. R. (1990). The role of institutions in the revival of trade: The law merchant, private judges, and the champagne fairs. Economics and Politics, 2(1), 1-23

North, D. C. (1989). Institutions and economic growth: An historical introduction. World Development, 17(9), 1319-1332

North, D. C. (1993). Institutions and credible commitment. Journal of Institutional and Theoretical Economics, 149(1), 11-23

North, D. C. (1994). The historical evolution of polities. International Review of Law and Economics 14, 381-391. 
North, D. C., \& Thomas, R. P. (1970). An economic theory of the growth of the Western World. The Economic History Review, 23(1), 1-17

Nunn N. (2007). Historical legacies: a model linking Africa’s past to its current underdevelopment. Journal of Development Economics 83, 157-175.

Nunn N. (2008). The long term effects of Africa's slave trades. Quarterly Journal of Economics 123(1): 139-176

Nunn, N., \& Wantchekon, L. (2011). The slave trade and the origins of mistrust in Africa. American Economic Review 101(7), 3221-3252.

Otite, O. (1978). The introduction: the study of social thought in Africa. In O. Otite (Ed.), Themes in African social and political thought (pp. 1-34). Enugu: Fourth Dimension Publishers

Oxelheim L, \& Randøy, T. (2003). The impact of foreign board membership on firm value. Journal of Banking and Finance 27(12), 2369-2392

Pfeffer, J., \& Salancik, G. R. (1978). The external control of organizations: A resource dependence perspective. New York: Harper \& Row

Raffournier, B. (1995). The Determinants of Voluntary Financial Disclosure by Swiss Listed Companies. European Accounting Review, 4, 261-80.

Raffournier, B. (1997). The Determinants of Voluntary Financial Disclosure by Swiss Listed Companies: a Reply. European Accounting Review, 6, 493-496.

Rau, R. (2015). Transparency and Executive Compensation. In J. Forssbaeck and L. Oxelheim (Eds.) The Oxford Handbook of Economic and Institutional Transparency, New York: Oxford University Press, pp. 413-433.

Sanders, W. M. G., \& Carpenter, M. A. (1998). Internationalization and firm governance: The roles of CEO compensation, top team composition and board structure. Academy of Management Journal, 41(2), 158-178

Scott, W. R. (1995). Institutions and organizations. Sage Publications Inc. 
Scott, W. R., Ruef, M., Mendel, P., \& Caronna, C. (2000). Institutional change and health care organizations: From professional dominance to managed care. Chicago: University of Chicago Press

Sidani, Y. M. \& Thornberry, J. (2013). Nepotism in the Arab World: An institutional theory perspective. Business Ethics Quarterly 23(1): 69-96

Suchman, M. C. (1995). Managing legitimacy: strategic and institutional approaches. The Academy of Management Review, 20(3): 571-610.

Suchman, M. C. (1995). Managing legitimacy: Strategic and institutional approaches. The Academy of Management Review, 20(3), 571-610

Thornton, P. H. (2002). The rise of the corporation in a craft industry: Conflict and conformity in institutional logics. Academy of Management Journal, 45, 81-101

Thornton, P. H. (2004). Markets from culture: Institutional logics and organizational decisions in higher education publishing. Stanford, CA: Stanford University Press

Thornton, P. H., \& Ocasio, W. (1999). "Institutional logics and the historical contingency of power in organizations: Executive succession in the higher education publishing industry, 19581990”. American Journal of Sociology, 105(3), 801-843

Thornton, P. H., Jones, C., \& Kury, K. (2005). “Institutional logics and institutional change: Transformation in Accounting, Architecture, and Publishing”, in Research in the Sociology of Organizations, ed. Candace Jones and Patricia H. Thornton, 125-170. London: JAI

Thornton, P. H., \& Ocasio, W. (2008). Institutional Logics. in the Sage Handbook of

Organizational Institutionalism, Second Edition, ed. R. Greenwood, C. Oliver, K. Sahlin \& R. Suddaby. Sage Publications

Transparency International. (2014). Corruption perceptions index. http://www.transparency.org/ Accessed 15 September 2014

Verrecchia, R.E. (2001). Essays on Disclosure. Journal of Accounting and Economics 32, 97-180

Weber, M. (1978). Economy and society. Berkeley: University of California Press 
West, A. (2014). Ubuntu and business ethics: Problems, perspectives and prospects. Journal of Business Ethics, 121: 47-61

Westphal, J. D., \& Zajac, E. J. (1994). Substance and symbolism in CEO’s long-term incentive plans. Administrative Science Quarterly, 39, 367-390

Wooldridge, J. M. (2009). Introductory econometrics: a modern approach. Cengage Learning. p. 865. ISBN 0-324-58162-9

Wooldridge, J. M. (2010). Econometric Analysis of Cross Section and Panel Data. 2nd ed. Cambridge, MA: MIT Press

World Bank Governance indicators. (2014). World Bank Governance Indicators. http://info.worldbank.org/governance/wgi/index.asp Accessed 15 September 2014

Zajac, E. J., \& Westphal, J. D. (2004). The social construction of market value: Institutionalization and learning perspectives on stock market reactions. American Sociological Review, 69, 433-458 


\section{Table 1. Institutional and governance frameworks of African financial markets}

This table outlines the corporate governance regime's (or principles) origins alongside its recommendations for disclosure of executive salary for indigenous firms. Details of the

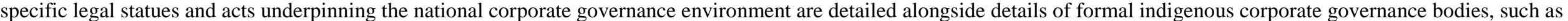

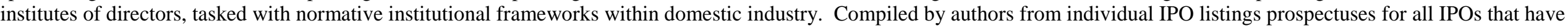
taken place across Africa between January 2000 and January 2014 as well as national stock exchange regulator websites

\begin{tabular}{|c|c|c|c|c|c|}
\hline Country & $\begin{array}{l}\text { Corporate } \\
\text { Governance } \\
\text { Principles }\end{array}$ & $\begin{array}{l}\text { Recommendation } \\
\text { to disclose } \\
\text { amount of } \\
\text { executive salary? }\end{array}$ & $\begin{array}{l}\text { Recommendation } \\
\text { to disclose } \\
\text { individual } \\
\text { amount of } \\
\text { executive salary? }\end{array}$ & Corporate Governance Legal Framework & $\begin{array}{l}\text { Additional } \\
\text { Corporate } \\
\text { Governance } \\
\text { Institutions }\end{array}$ \\
\hline \multicolumn{6}{|l|}{ North Africa } \\
\hline Algeria & OECD Principles & Yes - Statutory & No & $\begin{array}{l}\text { Code of Commerce; Securities Law and regulations by COSOB; Algerian } \\
\text { corporate governance code }\end{array}$ & $\begin{array}{l}\text { Hawkama El } \\
\text { Djazair (Endorsed } \\
\text { by the Ministry of } \\
\text { SMEs) }\end{array}$ \\
\hline Egypt & OECD Principles & Yes & No & $\begin{array}{l}\text { Company Law No } 159 \text { and its Executive Regulations No 96; Capital Market } \\
\text { Law No } 95 \text { and its Executive Regulations No 135; CMA's Decree No } 30 \\
\text { Board of Directors on Securities and De-Listing Rules of the Cairo and } \\
\text { Alexandria; Code of Corporate Governance for the private sector; Code of } \\
\text { Corporate Governance for State-Owned Enterprises }\end{array}$ & $\begin{array}{l}\text { Egyptian Institute } \\
\text { of Directors }\end{array}$ \\
\hline Morocco & OECD Principles & No & No & $\begin{array}{l}\text { Law 17-95 (30 august 1996, completed on 23rd may 2008) governing public } \\
\text { limited liability companies; Law n¹-93-212 (21st of September } 1993 \\
\text { amended several times) creating CDVM and all information required from } \\
\text { listed companies; Code of Good Corporate Governance Practices (and } \\
\text { annexes on corporate governance of SMEs and banks); Code on Corporate } \\
\text { Governance of SOEs }\end{array}$ & $\begin{array}{l}\text { National } \\
\text { Commission of } \\
\text { Corporate } \\
\text { Governance }\end{array}$ \\
\hline Tunisia & OECD Principles & Yes - Advisory & Yes - Advisory & $\begin{array}{l}\text { Code des Sociétés Commerciales (CSC, Code of Commercial Firms); Stock } \\
\text { market regulation by Conseil du Marché Financier (Tunisian securities } \\
\text { regulator ); Code of Best Practice of Corporate Governance Guidelines on } \\
\text { corporate governance for the banking sector }\end{array}$ & $\begin{array}{l}\text { L'Institut Arabe } \\
\text { des Chefs } \\
\text { d'Entreprises }\end{array}$ \\
\hline \multicolumn{6}{|l|}{ East Africa } \\
\hline Kenya & UK Cadbury Report & Yes - Advisory & Yes - Advisory & $\begin{array}{l}\text { Companies Act (Cap } 486 \text { of the Laws of Kenya); Capital Markets Act (Cap } \\
\text { 485A of the Laws of Kenya); The Capital Markets (Securities) (Public Offers, } \\
\text { Listing and Disclosures) Regulations 2002; Capital Markets Authority } \\
\text { established by the Capital Markets Act (Cap 485A); the State Corporations } \\
\text { Act, 1986; the Cooperatives Act }\end{array}$ & $\begin{array}{l}\text { Institute of } \\
\text { Directors - Kenya }\end{array}$ \\
\hline Tanzania & UK Cadbury Report & Yes - Advisory & No & $\begin{array}{l}\text { The Companies Act (2002), Cap } 212 \text { (the CA) and the Capital Markets and } \\
\text { Securities Act (1994); Public Corporations Act (1992) }\end{array}$ & $\begin{array}{l}\text { Institute of } \\
\text { Directors - } \\
\text { Tanzania }\end{array}$ \\
\hline Uganda & UK Cadbury Report & No & No & $\begin{array}{l}\text { The Companies Act (1961); Provisional draft code of corporate governance } \\
\text { (best practice - not ratified) }\end{array}$ & $\begin{array}{l}\text { The Institute of } \\
\text { Corporate } \\
\text { Governance of }\end{array}$ \\
\hline
\end{tabular}




\section{Rwanda}

OECD Principles

No

No

Mauritius

OECD Principles/ SA King I/ II/ III

Seychelles

OECD Principles

No - Aggregate board only

\section{West Africa}

Nigeria

UK Cadbury Report $\quad$ Yes - Advisory

No

BVRM

OECD Principles

No

No

Ghana

UK Cadbury Report

Yes - Advisory

Yes - Advisory

Cameroon OECD Principles

No

No

Cape Verde

Islands

Sierra Leone

UK Cadbury Report

No
Capital Market Regulation (Law No 11/2011); Company Law (Law No. 07/2009 of 27/04/2009)

Financial Reporting Act (2004); The Companies Act (2001); Financial Services Development Act 2001 and the Banking Act.

Securities Act (2007); Companies Ordinance (1972); Financial Services Authority Act (2013); Financial Institution Act (2004); Anti-Money

Laundering Act (2006); Voluntary Code of Conduct recommendations

Companies and Allied Matters Act, 1990; the Banks and Other Financial Institutions Act, 1991; the Investments and Securities Act, 1999; the

Securities and Exchange Commission Act, 1988; Voluntary code of Best

Practice for Public Companies (established by SEC, 2008)

The Union Economique et Monétaire de l'Afrique de l'Ouest (UEMOA) zone

has adopted the OHADA legal framework (Organization for Harmonization of Business Laws in Africa). The main statute that governs companies is the Uniform OHADA Act on company law (Acte Uniforme de OHADA relatif au droit des sociétés commerciales et du Groupement d'intérêt économique, or AUSCGIE), adopted in 1997. UEMOA countries share a common securities regulator (Le Conseil Régional de l'Epargne Publique et des Marchés Financiers, or CREPMF) and stock exchange (the BRVM)

The Companies Code 1963, the Securities Industry Law 1993 and the Regulations of the Ghana Stock Exchange

Règlement Général de la Commission des Marchés Financiers (CMF);

OHADA legal framework (Organization for Harmonization of Business Laws in Africa). The main statute that governs companies is the Uniform OHADA

Act on company law (Acte Uniforme de OHADA relatif au droit des sociétés commerciales et du Groupement d'intérêt économique, or AUSCGIE) adopted in 1997.

Código dos Valores Mobiliários"o Código de Mercado dos Valores

Mobiliários, aprovado pela Lei n.o 52/V 198, de 11 de Maio ; Código das

Empresas Comerciais" o Código aprovado pelo Decreto-Lei n.o 3/99, de 29 de

Março

The Companies Act (2009); National corporate governance code not yet drafted; Sierra Leone stock exchange operations and regulation governed by the Interim Stock Trading Rules and Regulations (not ratified in parliament)
Uganda

$-$

National

Committee on

Corporate

Governance;

Mauritius Institute

of Directors

No/ None

Institute of

Directors -

Nigeria

Director training organization (the Institut Sénégalais des

Administrateurs, or ISA) created in 2005

Institute of

Directors - Ghana

-- --

No/ None

No/ None 


\begin{tabular}{|c|c|c|c|c|c|}
\hline Botswana & $\begin{array}{l}\text { Sri Lanka Corporate } \\
\text { Governance Code/ } \\
\text { SA King II }\end{array}$ & Yes - Advisory & No & Botswana Stock Exchange Act (1994); The Companies Act (2003) & $\begin{array}{l}\text { Institute of } \\
\text { Directors - } \\
\text { Botswana }\end{array}$ \\
\hline Malawi & $\begin{array}{l}\text { Kenyan Corporate } \\
\text { Governance Code/ } \\
\text { SA King II }\end{array}$ & Yes - Advisory & No & $\begin{array}{l}\text { The Companies Act (1984); Malawi Stock Exchange Regulations; Financial } \\
\text { firms have to additionally comply with the Banking Act (1989) and licensing } \\
\text { by Reserve Bank of Malawi }\end{array}$ & $\begin{array}{l}\text { Institute of } \\
\text { Directors - } \\
\text { Malawi }\end{array}$ \\
\hline Zambia & UK Cadbury Report & No & No & Securities Act (1993); Companies Act Cap 388 & $\begin{array}{l}\text { Institute of } \\
\text { Directors - } \\
\text { Zambia }\end{array}$ \\
\hline Namibia & SA King I/ II/ III & Yes & Yes & $\begin{array}{l}\text { Namibia Companies Act (2004); State-owned Enterprises governance Act } \\
\text { (2006); Anti-Corruption Act (2003); Stock Exchange Control Act (1985-01) }\end{array}$ & ---- \\
\hline Mozambique & OECD Principles & No & No & $\begin{array}{l}\text { Código Comercial (new Commercial Code) (2006); Código Comercial } \\
\text { (Commercial Code) (2005); Anti-Corruption Law (2004); Competition Policy } \\
\text { and Law (2008); Regulamento do Mercado de Valores Mobiliários, conforme } \\
\text { disposto no Decreto No } 48 / 98 \text { de } 22 \text { de Setembro }\end{array}$ & $\begin{array}{l}\text { Instituto de } \\
\text { Directores de } \\
\text { Moçambique }\end{array}$ \\
\hline South Africa & SA King I/ II/ III & Yes & Yes & $\begin{array}{l}\text { Corporate Law Amendment Act (2007); Companies Bill (2007); Securities } \\
\text { Services Act (2005); King III best practice guideline recommendations }\end{array}$ & $\begin{array}{l}\text { Institute of } \\
\text { Directors - South } \\
\text { Africa }\end{array}$ \\
\hline
\end{tabular}


Table 2. Descriptive statistics for CEO salary disclosure and institutional environment

This table outlines the country averages of firm-level disclosure of CEO cash-based salary alongside details of formal and then informal institutional contexts. Formal outlines the legal family to which the national legal system originates according to La Porta et al (2008). Institutional quality - which is the average of the six World Bank governance metrics (democratic voice and accountability, rule of law, regulatory quality, political stability and absence from terrorism, government effectiveness and corruption control) as developed by Kaufman et al (2009). Ratio social elites is the average proportion of nonexecutives drawn from four designated social elites back grounds (military, government, commercial and academic) to board size for all IPO firms within that national market. Informal institutional context measures are the NSD Macrodata's three measures of societal fractionalization (that associated with ethnicity, religion and linguistic). $\mathrm{N}$ is sample size of IPO firms

\begin{tabular}{|c|c|c|c|c|c|c|c|c|}
\hline \multirow[t]{4}{*}{ Market } & \multirow[t]{4}{*}{$\mathbf{N}$} & \multirow{3}{*}{$\begin{array}{l}\text { Disclosure } \\
\text { CEO } \\
\text { salary }\end{array}$} & \multicolumn{6}{|l|}{ Institutions } \\
\hline & & & \multicolumn{3}{|l|}{ Formal } & \multicolumn{3}{|l|}{ Informal } \\
\hline & & & Legal origin & $\begin{array}{l}\text { Institutional } \\
\text { quality }\end{array}$ & $\begin{array}{l}\text { Ratio social } \\
\text { elites }\end{array}$ & $\begin{array}{l}\text { Ethnic } \\
\text { fractionalization }\end{array}$ & $\begin{array}{l}\text { Religious } \\
\text { fractionalization }\end{array}$ & $\begin{array}{l}\text { Linguistic } \\
\text { fractionalization }\end{array}$ \\
\hline & & $\%$ & & $\%$ & $\%$ & $\%$ & $\%$ & $\%$ \\
\hline \multicolumn{9}{|l|}{ North Africa } \\
\hline Algeria & 4 & 100.00 & French civil code & 28.97 & 6.20 & 33.94 & 0.91 & 44.27 \\
\hline Egypt & 10 & 30.00 & French civil code & 42.43 & 22.92 & 18.36 & 19.79 & 2.37 \\
\hline Morocco & 39 & 33.33 & French civil code & 46.94 & 6.24 & 48.41 & 0.35 & 46.83 \\
\hline Tunisia & 33 & 72.73 & French civil code & 50.84 & 1.38 & 3.94 & 1.04 & 1.24 \\
\hline \multicolumn{9}{|l|}{ East Africa } \\
\hline Kenya & 10 & 40.00 & English common law & 40.07 & 49.63 & 85.88 & 77.65 & 88.60 \\
\hline Tanzania & 9 & 22.22 & English common law & 45.36 & 42.05 & 73.53 & 63.34 & 89.83 \\
\hline Uganda & 6 & 0.00 & English common law & 38.55 & 42.17 & 93.02 & 63.32 & 92.27 \\
\hline Rwanda & 2 & 0.00 & French civil code & 47.91 & 24.26 & 32.38 & 50.66 & 0.00 \\
\hline Mauritius & 3 & 66.67 & French civil code & 71.55 & 27.78 & 46.34 & 63.85 & 45.47 \\
\hline Seychelles & 1 & 100.00 & French civil code & 57.01 & 22.22 & 20.25 & 23.23 & 16.06 \\
\hline \multicolumn{9}{|l|}{ West Africa } \\
\hline Nigeria & 26 & 69.23 & English common law & 29.56 & 29.39 & 85.05 & 74.21 & 85.03 \\
\hline BVRM & 7 & 0.00 & French civil code & 41.68 & 1.68 & 82.04 & 75.51 & 78.42 \\
\hline Ghana & 16 & 68.75 & English common law & 53.53 & 21.26 & 67.33 & 79.87 & 67.31 \\
\hline Cameroon & 2 & 0.00 & French civil code & 35.95 & 3.57 & 86.35 & 73.38 & 88.98 \\
\hline Cape Verde Islands & 4 & 0.00 & Portuguese civil code & 63.19 & 9.47 & 41.74 & 7.66 & 0.00 \\
\hline Sierra Leone & 2 & 50.00 & English common law & 38.57 & 65.00 & 81.91 & 53.95 & 76.34 \\
\hline \multicolumn{9}{|l|}{ Southern Africa } \\
\hline Botswana & 7 & 85.71 & English common law & 69.21 & 19.55 & 41.02 & 59.86 & 41.10 \\
\hline Malawi & 4 & 50.00 & English common law & 45.89 & 13.57 & 67.44 & 81.92 & 60.23 \\
\hline Zambia & 6 & 50.00 & English common law & 45.04 & 38.33 & 78.08 & 73.59 & 87.34 \\
\hline Namibia & 2 & 100.00 & English common law* & 61.84 & 25.60 & 63.29 & 66.26 & 70.05 \\
\hline Mozambique & 2 & 50.00 & Portuguese civil code & 47.19 & 34.17 & 69.32 & 67.59 & 81.25 \\
\hline South Africa & 7 & 100.00 & English common law* & 61.37 & 16.19 & 75.17 & 86.03 & 86.52 \\
\hline Africa overall & 202 & 51.49 & & 46.30 & 18.66 & 58.85 & 52.91 & 56.80 \\
\hline
\end{tabular}




\section{Table 3. Correlation analysis}

This table reports the Pearson correlations between all variables included in our study. These are the CEO salary disclosure - being a binary variable adopting value 1 if CEO's salary is disclosed in listing prospectus and 0 otherwise. Five cash flow ownership variables are included with these being percentage retained ownership of venture capitalists (VC), business groups, corporate block shareholders, executive directors and state entities. Two formal institutional variables are legal origin taking value 1 if jurisdiction is civil code law and 0 otherwise i.e. if common law. Three informal institutional variables are introduced with these being national fractions of ethnic diversity, religious diversity and linguistic diversity. Our three board variables are board size in terms of total number of executive and nonexecutive directors, board independence ratio, being ratio of independent unaffiliated nonexecutives to board size, and ratio social elites on board - defined as number of nonexecutives drawn from social elite backgrounds (senior military, government, university and commercial) to board size. Log (revenues) is natural logarithm of pre-tax firm revenues while ROA is accounting return to assets. Log (age) is natural logarithm of time (in years) between IPO year and year of establishment. Ratio total debt to total assets is a measure of leverage or gearing (see Bruton et al, 2010) with this being total debt divided by total asset value. Finally shares offered at IPO to total shares issued is our last IPO related control variable included.

\begin{tabular}{|c|c|c|c|c|c|c|c|c|c|c|}
\hline & & 1 & 2 & 3 & 4 & 5 & 6 & 7 & 8 & 9 \\
\hline 1 & CEO salary disclosure & 1.000 & & & & & & & & \\
\hline 2 & Ratio social elite nonexecutives & $-0.127 *$ & 1.000 & & & & & & & \\
\hline 3 & Institutional quality & $0.186^{* * *}$ & $-0.168 * *$ & 1.000 & & & & & & \\
\hline 4 & Civil code law (legal origin) & $-0.126^{*}$ & $-0.497 * * *$ & 0.039 & 1.000 & & & & & \\
\hline 5 & Fraction ethnic diversity & $-0.194 * * *$ & $0.432 * * *$ & $-0.317 * * *$ & $-0.697 * * *$ & 1.000 & & & & \\
\hline 6 & Log (board size) & $-0.141^{*}$ & $-0.257 * * *$ & $-0.170 * *$ & $0.223 * * *$ & -0.027 & 1.000 & & & \\
\hline 7 & Outsider nonexecutive ratio & 0.088 & $0.300 * * *$ & $0.166 * *$ & $-0.267 * * *$ & 0.145 & $-0.330 * * *$ & 1.000 & & \\
\hline 8 & Business Group directors ratio & 0.007 & $-0.214 * * *$ & -0.045 & $0.269 * * *$ & $-0.208 * * *$ & 0.068 & $-0.216^{* * *}$ & 1.000 & \\
\hline 9 & Ratio foreign nonexecutives & 0.037 & -0.043 & $0.179 * *$ & $-0.149 \dagger$ & 0.061 & 0.019 & -0.006 & -0.038 & 1.000 \\
\hline 10 & Log (revenue) & -0.045 & 0.060 & -0.059 & -0.006 & 0.011 & $0.228 * * *$ & $0.099 \dagger$ & 0.032 & 0.018 \\
\hline 11 & ROA & 0.094 & 0.091 & $0.104 \dagger$ & -0.057 & 0.000 & $-0.125^{*}$ & $0.094 \dagger$ & -0.062 & -0.044 \\
\hline 12 & Log (firm age) & -0.068 & -0.043 & $-0.133^{*}$ & 0.061 & 0.073 & $0.127 *$ & -0.054 & -0.018 & 0.046 \\
\hline 13 & Debt to equity ratio & $-0.112 * *$ & -0.025 & 0.036 & -0.006 & 0.052 & -0.016 & 0.183 & -0.002 & 0.066 \\
\hline 14 & CEO ownership & $0.218 * * *$ & -0.042 & $0.104 \dagger$ & -0.047 & -0.084 & $-0.243 * * *$ & 0.064 & -0.091 & 0.041 \\
\hline 15 & State ownership & $-0.120 * *$ & $0.256^{* * *}$ & $-0.106 \dagger$ & 0.044 & -0.005 & $0.191^{* * *}$ & $-0.179 * * *$ & $-0.243 * * *$ & -0.058 \\
\hline 16 & Aggregate block ownership & 0.029 & $-0.399 * * *$ & $0.153^{*}$ & $0.410 * * *$ & $-0.366^{* * *}$ & 0.046 & -0.087 & $0.522 * * *$ & 0.000 \\
\hline 17 & Shares offered / total shares & 0.049 & $0.134 *$ & $-0.112 \dagger$ & $-0.314^{* * *}$ & $0.174^{*}$ & -0.040 & $0.115 \dagger$ & -0.121 & 0.021 \\
\hline 18 & Lead Manager reputation & $-0.103 * *$ & 0.066 & -0.025 & -0.040 & $0.158^{*}$ & $0.114 \dagger$ & $0.095 \dagger$ & $-0.030 \dagger$ & 0.010 \\
\hline 19 & Lead Manager is foreign & $0.137 *$ & 0.041 & 0.004 & $-0.103 \dagger$ & $0.120 \dagger$ & -0.072 & $0.190 * * *$ & $-0.178 * *$ & 0.008 \\
\hline
\end{tabular}

$\dagger \mathrm{p}<0.10$; * $\mathrm{p}<0.05$; ** $\mathrm{p}<0.01$; *** $\mathrm{p}<0.005$ 
Table 3. Correlation analysis (continued)

\begin{tabular}{|c|c|c|c|c|c|c|c|c|c|c|c|}
\hline & & 10 & 11 & 12 & 13 & 14 & 15 & 16 & 17 & 18 & 19 \\
\hline 1 & CEO salary disclosure & & & & & & & & & & \\
\hline 2 & Ratio social elite nonexecutives & & & & & & & & & & \\
\hline 3 & Institutional quality & & & & & & & & & & \\
\hline 4 & Civil code law (legal origin) & & & & & & & & & & \\
\hline 5 & Fraction ethnic diversity & & & & & & & & & & \\
\hline 6 & Log (board size) & & & & & & & & & & \\
\hline 7 & Outsider nonexecutive ratio & & & & & & & & & & \\
\hline 8 & Business Group directors ratio & & & & & & & & & & \\
\hline 9 & Ratio foreign nonexecutives & & & & & & & & & & \\
\hline 10 & Log (revenue) & 1.000 & & & & & & & & & \\
\hline 11 & ROA & 0.032 & 1.000 & & & & & & & & \\
\hline 12 & Log (firm age) & $0.223 * * *$ & -0.037 & 1.000 & & & & & & & \\
\hline 13 & Debt to equity ratio & 0.004 & $0.096 \dagger$ & $-0.124 *$ & 1.000 & & & & & & \\
\hline 14 & CEO ownership & $-0.203 * * *$ & 0.017 & $-0.211 * * *$ & 0.028 & 1.000 & & & & & \\
\hline 15 & State ownership & $0.182 * * *$ & -0.059 & $0.115 \dagger$ & -0.088 & $-0.210 * * *$ & 1.000 & & & & \\
\hline 16 & Aggregate block ownership & -0.035 & -0.052 & 0.013 & -0.071 & $-0.118 \dagger$ & $-0.456 * * *$ & 1.000 & & & \\
\hline 17 & Shares offered / total shares & $-0.196 * * *$ & 0.018 & $-0.147 *$ & -0.033 & 0.041 & $-0.104 \dagger$ & $-0.234 * * *$ & 1.000 & & \\
\hline 18 & Lead Manager reputation & $0.283^{* * *}$ & -0.005 & 0.084 & 0.028 & -0.065 & 0.000 & -0.062 & $-0.132 *$ & 1.000 & \\
\hline 19 & Lead Manager is foreign & $0.147^{*}$ & $0.094 \dagger$ & 0.025 & 0.035 & 0.041 & 0.031 & $-0.203 * * *$ & 0.019 & $0.428 * * *$ & 1.000 \\
\hline
\end{tabular}


Table 4. The association between institutions and CEO salary disclosure $\mathrm{e}^{\mathrm{a}, \mathrm{b}, \mathrm{c}}$

This table presents the logistic regression model results for binary dependent variable (1/0) likelihood of disclosure of CEO salary onto our explanatory and control variables. These are defined in Table 3.

\section{Intercept \\ Hypothesis testing \\ H1: Ratio social elites \\ H2: Ratio social elites $\mathrm{x}$ Institutional quality \\ H3: Civil code law \\ H4: Ethnic fractionalization \\ Formal institutional control Institutional quality \\ Board controls \\ Log (board size) \\ Outsider nonexecutive ratio \\ Business Group directors ratio \\ Ratio foreign nonexecutives}

\section{Firm controls}

Log (Revenue)

ROA

Log (Firm Age)

Debt to equity ratio

\section{Ownership controls}

CEO ownership

State ownership

Aggregate block ownership

\section{IPO controls}

Shares Offered/ Total Shares

Lead Manager reputation

Lead Manager is foreign

No Obs. $=0$

No Obs. $=1$

No. Obs.

AIC criterion

SBC criterion

HQC criterion

LR statistic (prob.)

McFadden $\mathrm{R}^{2}$

\begin{tabular}{|c|c|c|c|}
\hline \multicolumn{4}{|c|}{ Likelihood of disclosure of CEO salary } \\
\hline \multicolumn{3}{|c|}{ Formal institutional environment } & \multirow{2}{*}{$\begin{array}{l}\begin{array}{l}\text {...and Informal } \\
\text { environment }\end{array} \\
\begin{array}{l}\text { Ethnic } \\
\text { fractionalization }\end{array}\end{array}$} \\
\hline Social elites & Moderation & Civil code law & \\
\hline Probit & Probit & Probit & Probit \\
\hline Model 1 & Model 2 & Model 3 & Model 4 \\
\hline $0.613[0.39]$ & $0.144[0.08]$ & $1.504[0.83]$ & $4.349[2.16]^{*}$ \\
\hline$-1.067[-1.96]^{*}$ & $0.974[0.36]$ & $-3.161[-1.30] \dagger$ & $-4.697[-1.42] \dagger$ \\
\hline---- & $-4.665[-0.77]$ & $2.843[0.42]$ & $7.233[1.33] \dagger$ \\
\hline -- -- & ---- & $-1.409[-3.99]^{* * *}$ & $-2.313[-4.74] * * *$ \\
\hline -- -- & ---- & -- -- & $-2.444[-3.27] * * *$ \\
\hline $1.852[1.49] \dagger$ & $2.776[1.69]^{*}$ & $1.365[0.72]$ & $-0.944[-0.45]$ \\
\hline$-1.276[-1.83]^{*}$ & $-1.308[-1.86]^{*}$ & $-0.977[-1.36] \dagger$ & $-0.341[-0.47]$ \\
\hline $0.070[0.13]$ & $0.226[0.39]$ & $-0.197[-0.34]$ & $-0.410[-0.71]$ \\
\hline $0.049[0.12]$ & $0.050[0.12]$ & $0.105[0.24]$ & 0.088 [0.19] \\
\hline$-0.333[-0.36]$ & $-0.309[-0.33]$ & $-1.049[-1.02]$ & $-0.791[-0.75]$ \\
\hline $0.225[1.45] \dagger$ & $0.224[1.46] \dagger$ & $0.192[1.30] \dagger$ & $0.120[0.73]$ \\
\hline $0.446[1.68]^{*}$ & $0.499[1.87]^{*}$ & 0.438 [1.69]* & $0.369[1.29]^{*}$ \\
\hline$-0.068[-0.23]$ & $-0.061[-0.21]$ & $0.073[0.23]$ & $0.228[0.71]$ \\
\hline$-0.088[-3.16]^{* * *}$ & $-0.089[-3.15]^{* * *}$ & $-0.090[-2.84] * * *$ & $-0.083[-2.44]^{* *}$ \\
\hline $0.013[1.81]^{*}$ & 0.013 [1.85]* & $0.018[2.50]^{* *}$ & $0.015[2.06]^{*}$ \\
\hline$-0.002[-0.25]$ & $-0.001[-0.07]$ & $0.005[0.77]$ & $-0.001[-0.11]$ \\
\hline$-0.004[-0.76]$ & $-0.004[-0.77]$ & $0.003[0.55]$ & $0.001[0.16]$ \\
\hline $0.108[0.18]$ & $0.086[0.14]$ & $-0.285[-0.41]$ & $-0.467[-0.66]$ \\
\hline$-1.126[-2.79]^{* * *}$ & $-1.099[-2.73]^{* * *}$ & $-1.172[-2.81]^{* * *}$ & $-1.102[-2.68] * * *$ \\
\hline $0.774[2.79]^{* * *}$ & $0.755[2.73]^{* * *}$ & $0.815[2.75]^{* * *}$ & $0.848[2.63]^{* * *}$ \\
\hline 88 & 88 & 88 & 88 \\
\hline 96 & 96 & 96 & 96 \\
\hline 184 & 184 & 184 & 184 \\
\hline 1.442 & 1.451 & 1.387 & 1.348 \\
\hline 2.124 & 2.150 & 2.104 & 2.082 \\
\hline 1.719 & 1.734 & 1.678 & 1.646 \\
\hline $67.32[0.00]$ & $67.74[0.00]$ & $81.48[0.00]$ & $90.68[0.00]$ \\
\hline 0.2643 & 0.2659 & 0.3199 & 0.3560 \\
\hline
\end{tabular}

${ }^{\mathrm{a}}$ Dummy variables for year and industry were included in the models but are not reported in the table; ${ }^{\mathrm{b}}$ Z-statistics are in parentheses; ${ }^{\mathrm{c}}$ QML (Huber/White) standard errors \& covariance; $\dagger \mathrm{p}<0.10$; ${ }^{*} \mathrm{p}<0.05$; ${ }^{* *} \mathrm{p}<0.01$; *** $\mathrm{p}<$ 0.005 
Figure 1. Probability chart relating likelihood of CEO pay disclosure with proportion of social elites on board and institutional quality

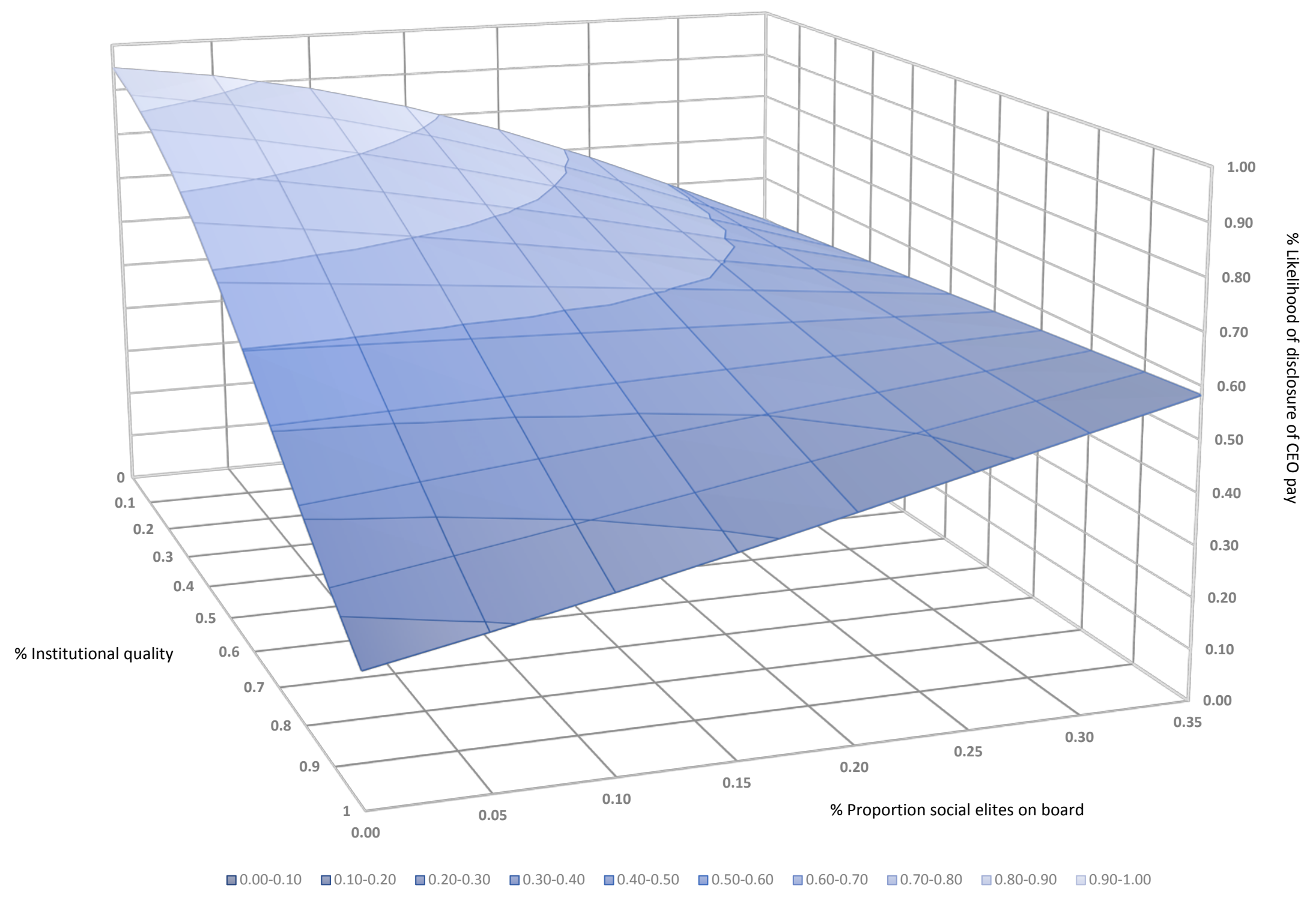




\section{Appendix Table 1. Data sources}

\begin{tabular}{|c|c|}
\hline Market & Information source \\
\hline North Africa & $\begin{array}{l}\text { Databases: Al Zawya (see website at: http://www.zawya.com/); Mubasher investment reporting } \\
\text { (http://www.mubasher.net/en/Index.aspx); Bloomberg LLP; Business Week }\end{array}$ \\
\hline Algeria & $\begin{array}{l}\text { Websites: Bourse d'Algérie [SGBV] (htp://www.sgbv.dz); Commission d'Organisation et des } \\
\text { Surveillance des Opérations de Bourse [COSOB] (http://www.cosob.org/) } \\
\text { Telephone interviews and direct correspondence: M. Hamdi and Mme. Haffar (Bourse d'Alger) }\end{array}$ \\
\hline Egypt & $\begin{array}{l}\text { Websites: Egyptian Stock Exchange [EGX] (http://www.egx.com.eg/english/homepage.aspx); } \\
\text { The Egyptian Financial Supervisory Authority } \\
\text { (http://www.efsa.gov.eg/content/IFIE/about_efsa.html); Central Bank of Egypt } \\
\text { (http://www.cbe.org.eg/English/) } \\
\text { Telephone interviews (unstructured) to obtain data: Mohammed Omran (Chairman, EGX) } \\
\text { Cairo-based interviews: Ayman Raafat (Market Control, EGX); Hebatallah El Serafi (Research \& } \\
\text { Market Development, EGX); Yasmin El-Khatib (PR \& Communications, EGX) }\end{array}$ \\
\hline
\end{tabular}

Morocco

Websites: Bourse de Casablanca (http://www.casablanca-bourse.com/); Le Conseil Déontologique des Valeurs Mobilières [CDVM] (http://www.cdvm.gov.ma/)

Casablanca-based interviews to obtain data: Mme. Meryem Tazi (Chef de Produits, Service

Marketing, Bourse de Casablanca); Mme. Amina Zouaoui (Analyste, Service Négociation, Bourse de Casablanca)

Tunisia $\quad$ Websites: Bourse de Tunis (http://www.bvmt.com.tn/); Conseil du Marché Financier [CMF] (http://www.cmf.org.tn/); Central Bank of Tunisia (http://www.bct.gov.tn/)

Tunis-based interviews: M. Hatem Zribi (Direction de la Promotion du Marché, Bourse de Tunis); Mme. Maher Chtourou (Banque Centrale de Tunisie library)

Tunis-based procurement of data from library of African Development Bank

Sub Saharan Africa

\section{East Africa} Kenya

Mauritius

Seychelles

Tanzania

Rwanda

Uganda

\section{West Africa}

Nigeria
Databases: African financials annual reports (http://www.africanfinancials.com/); Invest Africa annual reports (http://investinginafrica.net/african-stock-markets/); Thomson Perfect Information portal; Bloomberg LLP; Business Week

Websites: Nairobi securities exchange (https://www.nse.co.ke/); Capital Markets Authority Kenya (http://www.cma.or.ke/); Daily Nation business journal (http://www.nation.co.ke/)

Local Nairobi-based interviews: Public relations officer, Nairobi Stock Exchange; Investment Manager, Suntra Investment Bank, Kenya

Websites: Stock Exchange of Mauritius [SEM] (http://www.stockexchangeofmauritius.com/)

Websites: Trop-X Seychelles stock exchange (http://www.trop-x.com/)

Websites: Dar Es Salaam stock exchange (http://www.dse.co.tz/)

Telephone procurement of listing prospectus from M. Stimali, Tanzania Tea Packers Ltd

Websites: Rwanda stock exchange (http://rse.rw/); Capital Market Authority (http://cma.rw/)

Websites: Uganda securities exchange [USE] (http://www.use.or.ug/); Capital Markets Authority (http://www.cmauganda.co.ug/)

Procurement of annual reports: Kampala-based USE library

Kampala-based interviews: Investment Management team, Crane Bank, Kampala; Head of trading, USE trading floor, Kampala; Investment Manager, African Alliance Securities, Kampala; Head of equities trading, Standard Chartered Bank, Kampala

Websites: Nigerian stock exchange [NSE] (http://www.nse.com.ng/Pages/default.aspx); Securities and Exchange Commission Nigeria (http://www.sec.gov.ng/)

Lagos-based procurement of annual reports and listings prospectuses from NSE library, Lagos Lagos-based interviews: M. Obaseki (President of Operations, NSE); Mme. Hauwa M. Audu (Founder CEO, Amyn Investments and stockbroking, Lagos) 
Cote d'Ivoire:

Procurement of annual reports: Abidjan (Cote d'Ivoire)-based library for BRVM

Abidjan-based interviews:

BRVM exchange: Emmanuel Zamble (Market operations manager, BRVM); Khassim Diop (Chargée de développement du Marché, BRVM); Abdoulaye Sogoba (Assistant chargée de la formation, BRVM)

Abidjan brokers: M. Auguste Kouakou (Gniman-Finance SA, Abidjan); M. Hermann Boua (Hudson et Cie, Abidjan)

Mali: Bamako-based interviews: M. Amadou Djeri Bocoum (Directeur de l'Antenne Nationale de Bourse du Mali, Bamako); M. Alassane Sissoko (Responsable des études et de la négociation, Société de Gestion et d'Intermédiation (SGI) du Mali SA, Bamako)

Ghana

Cameroon

Cape Verde

Sierra Leone

\section{Southern Africa}

Botswana

Malawi

Zambia

Namibia

Mozambique

South Africa
Websites: Ghana stock exchange (http://www.gse.com.gh/)

Accra-based interviews:

Ghana stock exchange: Worlanyo Amoa (Senior Manager, Research and Product Devlopment, GSE) Ghana Brokers: Armah I. J. Akotey (Vice President, Databank Brokerage and Investment Banking, Accra, Ghana); Edem Akpenyo (HFC Brokerage Services, Accra, Ghana); Kafui Asare (Head of Client Relations, SAS Investment Management, Accra, Ghana); Haruna Gariba (Head of Client Relations, Merchant Bank of Ghana Ltd, Accra, Ghana)

Websites: Doula stock exchange (http://www.douala-stock-exchange.com/) Pretoria (South Africa)-based interviews: Cameroon Embassy, Pretoria, South Africa

Website: Cape Verde stock exchange [BVC] (http://www.bvc.cv/)

Telephone based interviews and procurement of data: Edmilson Mendonça (Operations Manager, BVC); Ronnie Machado (Compliance Manager, BVC)

Telephone-based interviews and procurement of data: M. Gibrilla Sesay (Operations Manager, Sierra Leone stock exchange); M. Michael Collier (Deputy President, Rokel Commercial Bank, Freetown, Sierra Leone); Jacob Kanu and Daniel Thomas (CEO’s of independent local licensed stockbrokers, Freetown)

Website: Botswana stock exchange [BSE] (http://www.bse.co.bw/)

Telephone interviews and data procurement: Kopane Bolokwe (Operations officer, BSE)

Gabarone-based interviews with Head of Operations, BSE; President of Stock Brokers Botswana

Websites: Malawi stock exchange [MSE] (http://www.mse.co.mw/); The Nation business journal (http://mwnation.com/)

Telephone interviews and data procurement: Malawi stock brokers, Blantyre, Malawi

Websites: Lusaka stock exchange [LuSE] (http://www.luse.co.zm/); The Post business journal (Zambia) (http://www.postzambia.com/)

Telephone-based procurement: Mme. Sitali Mugala (Operations Manager, Lusaka stock exchange)

Lusaka-based interviews: LuSE operations personnel

Websites: Namibia stock exchange [NSX] (http://nsx.com.na/)

Windhoek-based data procurement from NSX building and library

Telephone based procurement: John Mandy (CEO, NSX); Loide Nakanduungile (Research Manager, NSX); Manda Steynberg (Operations Manager, NSX)

Websites: Bolsa de Valores de Maputo [BVM] (http://www.bvm.co.mz/)

Maputo-based interviews: Señor Bruno Tembe (Técnico Superior, BVM); Señor Felisberto Navalha (Operations Manager, Central Bank of Mozambique)

Maputo-based procurement from Central Bank of Mozambique annex library, Baixa, Maputo

Websites: Johannesburg stock exchange [JSE] (https://www.jse.co.za/)

Telephone-based procurement: Market data department, JSE, Johannesburg. South Africa 


\section{Appendix Table 2. Institutional measures data sources}

\begin{tabular}{ll}
\hline Formal institutions & Definition \\
\hline $\begin{array}{l}\text { Worldwide Governance measures } \\
\text { Voice and Accountability }\end{array}$ & $\begin{array}{l}\text { capturing perceptions of the extent to which a country's citizens are able to } \\
\text { participate in selecting their government, as well as freedom of expression, freedom } \\
\text { of association, and a free media } \\
\text { capturing perceptions of the likelihood of political instability and/or politically- } \\
\text { motivated violence, including terrorism } \\
\text { Violence/ Terrorism } \\
\text { Government Effectiveness }\end{array}$ \\
$\begin{array}{l}\text { capturing perceptions of the quality of public services, the quality of the civil service } \\
\text { and the degree of its independence from political pressures, the quality of policy } \\
\text { formulation and implementation, and the credibility of the government's commitment } \\
\text { to such policies }\end{array}$ \\
capturing perceptions of the ability of the government to formulate and implement \\
sound policies and regulations that permit and promote private sector development \\
capturing perceptions of the extent to which agents have confidence in and abide by \\
the rules of society, and in particular the quality of contract enforcement, property \\
rights, the police, and the courts, as well as the likelihood of crime and violence \\
capturing perceptions of the extent to which public power is exercised for private \\
gain, including both petty and grand forms of corruption, as well as "capture" of the \\
state by elites and private interests
\end{tabular}

Underlying Source:

The WGI are based on a large number of different data sources, capturing the views and experiences of survey respondents and experts in the public and private sectors, as well as various NGOs. These data sources include: (a) surveys of households and firms (e.g. Afrobarometer surveys, Gallup World Poll, and Global Competitiveness Report survey), (b) NGOs (e.g. Global Integrity, Freedom House, Reporters Without Borders), (c) commercial business information providers (e.g. Economist Intelligence Unit, Global Insight, Political Risk Services), and (d) public sector organizations (e.g. CPIA assessments of World Bank and regional development banks, the EBRD Transition Report, French Ministry of Finance Institutional Profiles Database). For a complete list of sources used in the current update of the WGI refer to http://info.worldbank.org/governance/wgi/index.aspx\#faq

\begin{tabular}{l} 
Informal institutions \\
\hline Ethnicity fractionalization \\
Religion fractionalization \\
Language fractionalization \\
Index formulation
\end{tabular}

Definition

A representation of the major ethnic groups per country. Major ethnicities reported at a broad level of disaggregation thus mitigating consistency and comparability issues regarding inclusion of sub-ethnicities which are particularly prevalent in regions such as Sub Saharan Africa and parts of Asia. Most of the data used to compute the ethnic fractionalisation index are from the 1990s, but for some countries older data are used (as far back as 1979)

A representation of the major religions per country. The dataset contains data for only one year for each country. The language and religion indices are based on data from 2001

A representation of the major languages per country.

The indices are computed as one minus the Herfindahl index of group shares. The project provides a measurement of ethnic, linguistic, and religious fractionalisation which intends to be more comprehensive than those fractionalization measurements previously used in economics literature. The goal of this new measure of ethnic fragmentation, is a broader classification of groups, taking into account not only language but also racial characteristics (ethnicity) and religion. The dataset also contains the underlying data used to construct the indices

Underlying Source: The dataset covers 215 countries and territories. Indices based on population data collected from Encyclopaedia Britannica (2001), CIA's World Factbook (2000), Levinson's Ethnic Groups Worldwide (1998), and Minority Rights Group International's World Directory of Minorities (1997); in addition to Mozaffar \& Scarrit (1999) for selected African countries. In most cases the primary source is national censuses. Refer to NSD macrodata (Norway): http://www.nsd.uib.no/macrodataguide/set.html?id=16\&sub=1 The dataset is described in detail in Alesina et al. (2003)

Table documenting sources and construction behind formal and informal institutional controls used 